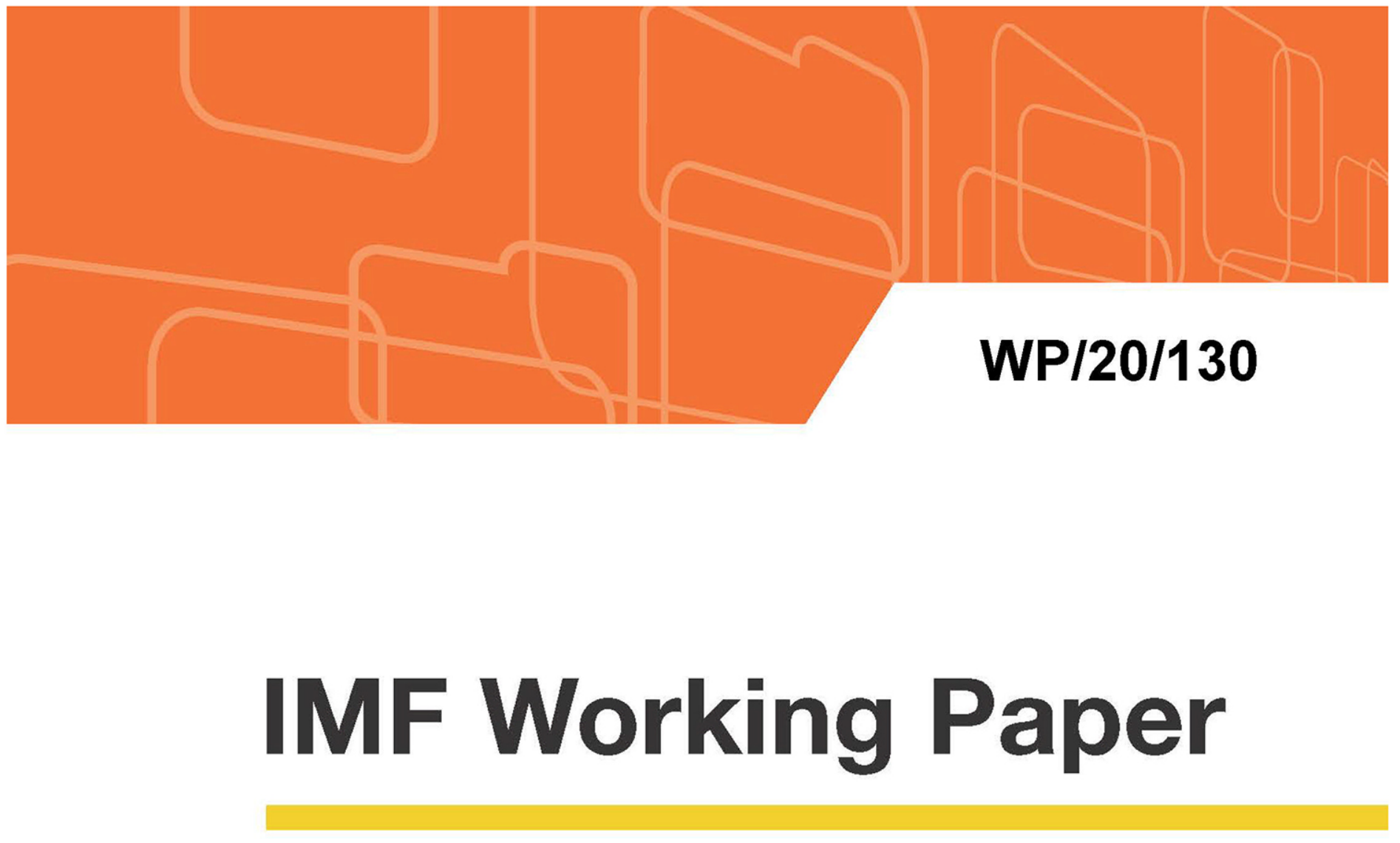

\title{
Public Sector Balance Sheet Database: Overview and Guide for Compilers and \\ Users
}

by Miguel Alves, Sagé De Clerck, and Juliana Gamboa-Arbelaez

IMF Working Papers describe research in progress by the author(s) and are published to elicit comments and to encourage debate. The views expressed in IMF Working Papers are those of the author(s) and do not necessarily represent the views of the IMF, its Executive Board, or IMF management. 


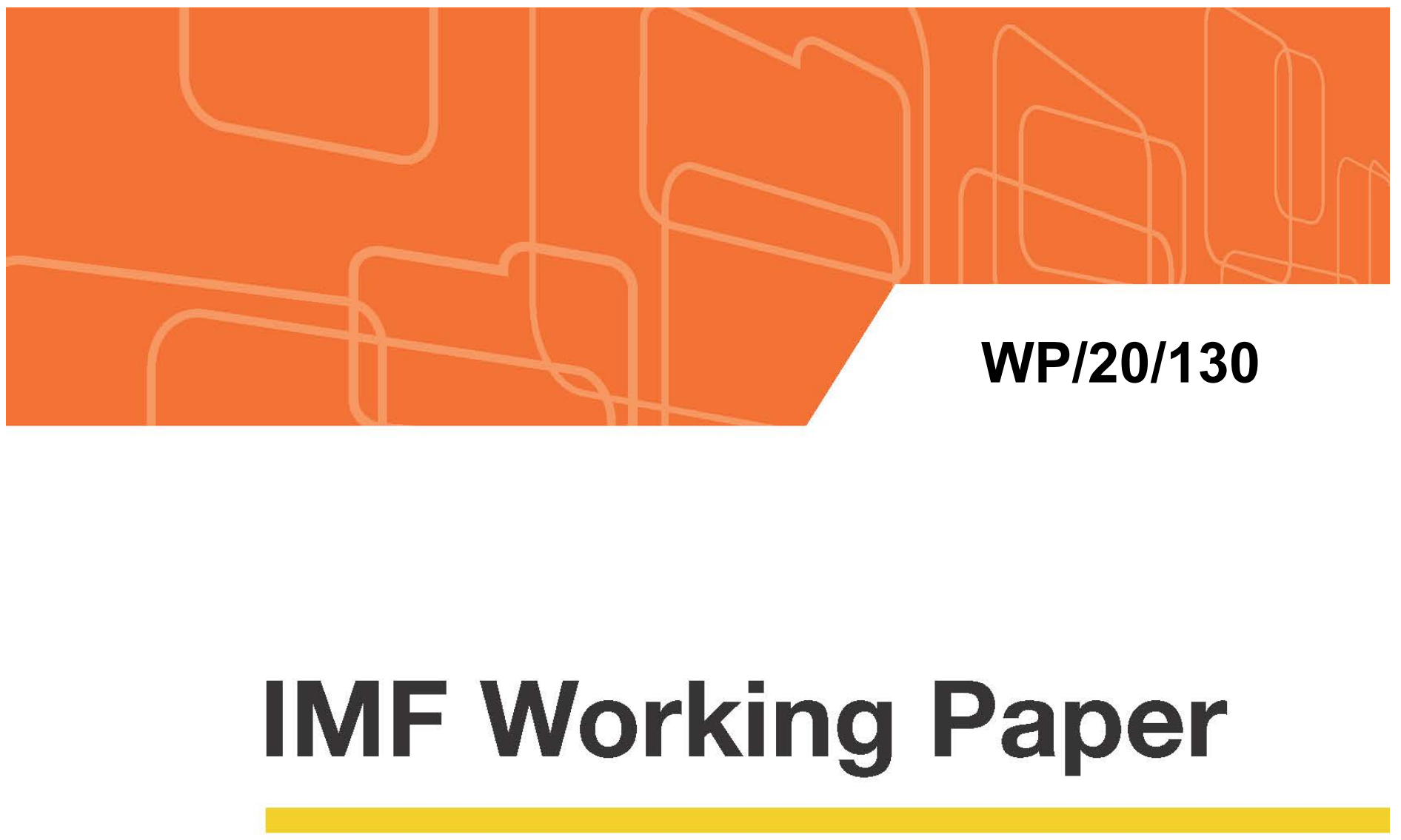

\section{Public Sector Balance Sheet Database: Overview and Guide for Compilers and \\ Users}

by Miguel Alves, Sagé De Clerck, and Juliana Gamboa-Arbelaez

IMF Working Papers describe research in progress by the author(s) and are published to elicit comments and to encourage debate. The views expressed in IMF Working Papers are those of the author(s) and do not necessarily represent the views of the IMF, its Executive Board, or IMF management.

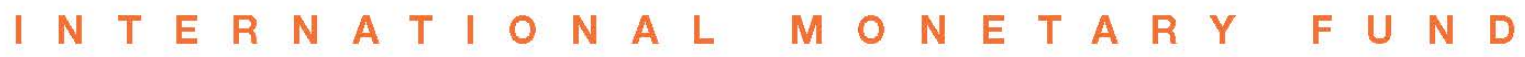




\title{
IMF Working Paper
}

\author{
Fiscal Affairs Department
}

\section{Public Sector Balance Sheet Database: Overview and Guide for Compilers and Users \\ Prepared by Miguel Alves, Sagé De Clerck, and Juliana Gamboa ${ }^{1}$ \\ (Under guidance of Jason Harris and Alexander Tieman)}

Authorized for distribution by Carolina Renteria

June 2020

IMF Working Papers describe research in progress by the author(s) and are published to elicit comments and to encourage debate. The views expressed in IMF Working Papers are those of the author(s) and do not necessarily represent the views of the IMF, its Executive Board, or IMF management.

\begin{abstract}
This paper provides an overview of the Public Sector Balance Sheet (PSBS) Database, a dataset developed in the context of the October 2018 Fiscal Monitor. The dataset provides a comprehensive picture of public wealth for 38 countries, and a narrower picture for further 37 countries and territories. Comprehensive PSBSs bring together all the accumulated assets and liabilities that governments control, including public corporations, natural resources, and pension liabilities. They therefore account for the entirety of what the state owns and owes, offering a broader fiscal picture beyond debt and deficits. This is particularly relevant in the current context of record and still rising debts and heightened risks to the balance sheet of the public sector. PSBSs bring about greater transparency and allow closer scrutiny of government's financial position. They also allow better balance sheet management, thereby potentially increasing return on assets, reducing risks and the costs of borrowing, and improving fiscal policymaking. The paper also elaborates on the conceptual framework and methodology used in compiling the data, and provides some practical guidelines on the compilation, validation, and dissemination of such data.
\end{abstract}

JEL Classification Numbers: H11, H13, H19, H29

Keywords: Assets, balance sheet, converting financial statements, liabilities, mineral and energy resources, net worth, pensions, public corporations, public sector, public sector balance sheet, public wealth

Authors' E-Mail Addresses: malves@imf.org; sdeclerck@imf.org; jgamboa@imf.org

\footnotetext{
${ }^{1}$ This paper was written as technical background for the chapter "Managing Public Wealth" in the October 2018 Fiscal Monitor. We are grateful for comments and suggestions by IMF colleagues, particularly Klakow Akepanidtaworn, Philip Barrett, Kay Chung, Majdeline El Rayess, Guohua Huang, lana Paliova, Edgardo Ruggiero, and Philip Stokoe, and participants of the March 2018 Workshop on Public Sector Balance Sheets held at the IMF. Views expressed are those of the authors and do not necessarily represent those of the IMF, its Executive Board or its management.
} 


\section{Contents}

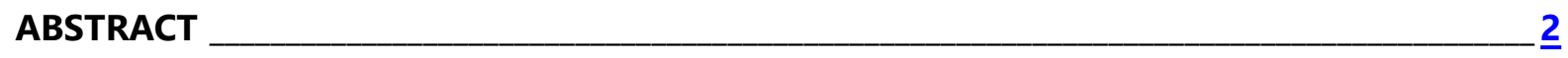

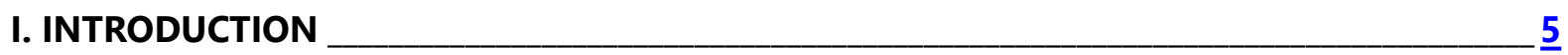

II. OVERVIEW OF THE PSBS DATABASE ________________________________________

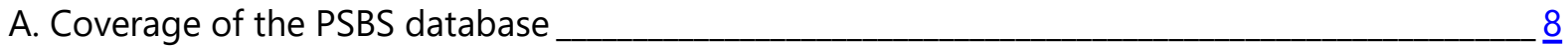

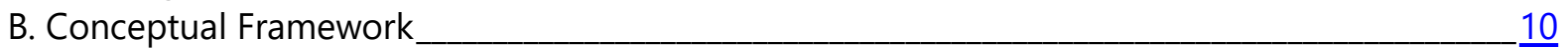

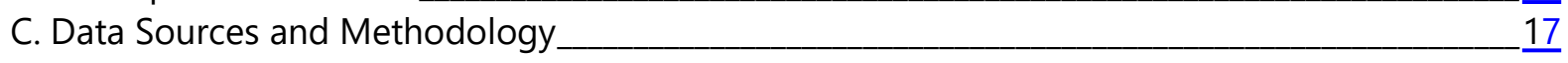

III. GLOBAL TRENDS AND APPLICATION IN FISCAL ANALYSIS _____

A. The Evolution of Public Sector Balance Sheets Over Time_______

B. Using Public Sector Balance Sheets in Fiscal Analysis__________ 27

IV. COMPILATION GUIDELINES ____________________________________

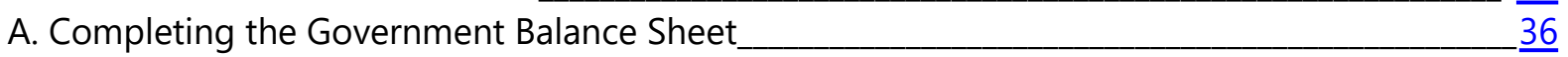

B. Converting Financial Statements into Government Finance Statistics ______ _ _ _

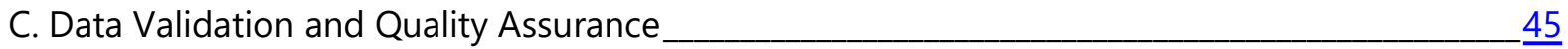

D. Dissemination and Revisions Policy _________________________________________________

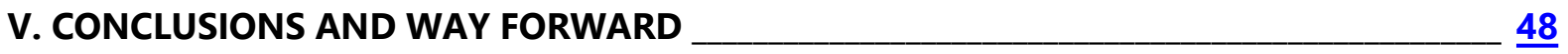

REFERENCES _____________________________________________________________

\section{BOXES}

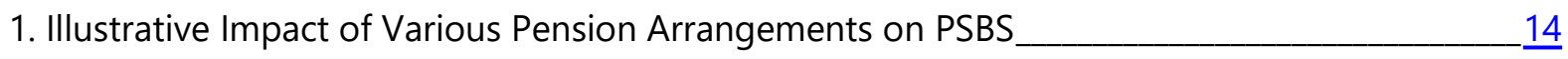

2. Funding Arrangements by type of Employment-Related Pension Schemes _______

3. Valuation Methods for Assets and Liabilities ___________________________________________________

\section{FIGURES}

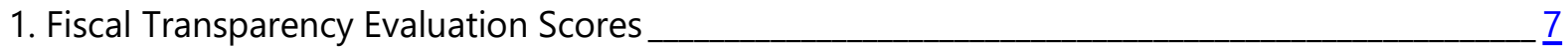

2. Institutional Coverage of the PSBS Dataset___________________________________________

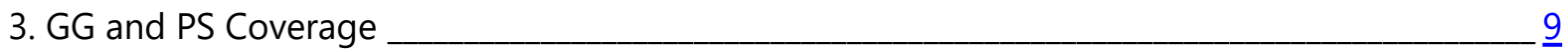

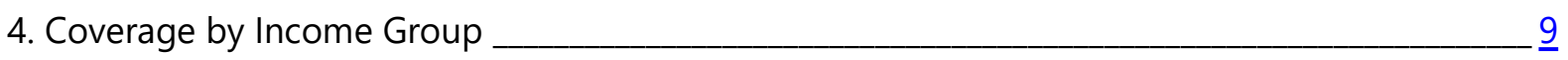

5. Coverage of Stocks Positions by Income Group and Level of Government _______

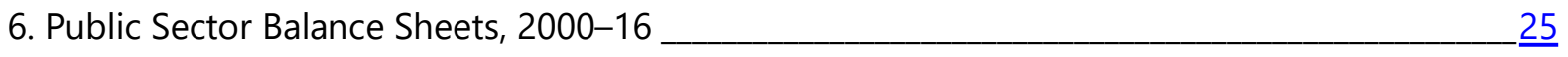

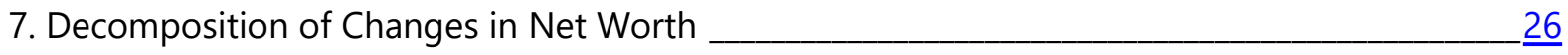

8. Equity Liabilities of Public Corporations, 2016

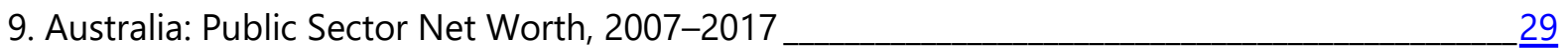

10. Public Sector Debt by Holding Sector, 2001-17_______________________________

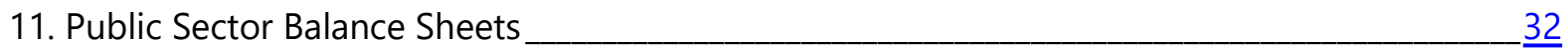

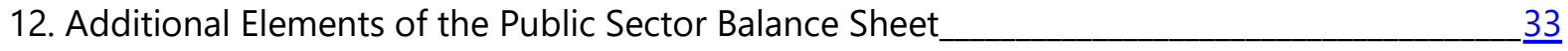


13. Equity Liabilities of Public Corporations, 2016

14. General Government Balance Sheets, 2016

\section{TABLES}

1. Public Sector Balance Sheet Database Coverage

2. Composition of the Public Sector Balance Sheet

3. Australia: Public Sector Balance Sheet, 2016

\section{APPENDICES}

I. Time Series Availability in the PSBS Database 49

II. Illustrative Conversion of Financial Statements to the PSBS Template $\underline{50}$ 


\section{INTRODUCTION}

Fiscal analysis continues to evolve, and the changed economic environment requires improvements in data to formulate and evaluate fiscal policies. The demand for internationally comparable data increases continuously in a more globalized world that requires better information to evaluate not only the performance of governments and their interconnectedness, but also the longer-term sustainability of their policy decisions.

Public sector balance sheets (PSBSs) provide the most comprehensive picture of public wealth. They bring together all the accumulated assets and liabilities that governments control, including public corporations, natural resources, and pension liabilities. They therefore account for the entirety of what the state owns and owes, offering a broader fiscal picture beyond debt and deficits. This is particularly relevant in the current context of record and still rising debts and heightened risks to the balance sheet of the public sector. PSBSs bring about greater transparency and allow closer scrutiny of government's financial position. They also allow better balance sheet management, thereby potentially increasing return on assets, reducing risks and the costs of borrowing, and improving fiscal policymaking.

The PSBS database focuses on all assets and all liabilities of the public sector. ${ }^{2}$ By doing that, it considerably expands the traditional focus on government debt, which misses large swaths of government activity, potentially leading governments to fall victim to illusory fiscal practices. ${ }^{3}$ The dataset goes beyond looking at cash and deposits as the only asset governments control, and comprehensively includes all nonfinancial assets as well as all financial instruments. On the liability side the dataset goes beyond traditional measures of debt to encompass estimates of all government liabilities including liabilities associated with government's obligation for pension benefit payments and equity liabilities. The dataset also extends institutional coverage beyond general government to encompass nonfinancial public corporations (also referred to as stateowned enterprises (SOEs) or parastatals) and financial public corporations including the Central Bank, which are often missed in fiscal analysis. These enterprises represent a significant asset for the government, but they can also generate significant claims on budgets-often governments accumulate fiscal risks in these entities that will need to be addressed in the future.

The balance sheet approach marks the next stage of an evolution of fiscal data that spans many decades. In the early 1970s a draft of A Manual on Government Finance Statistics was released. It eventually evolved into the IMF's A Manual on Government Finance Statistics of 1986 that focused primarily on the cash constraints of governments as depicted by the cash surplus/deficit. The second most important indicator was the outstanding debt, illustrating the focus on how these

\footnotetext{
${ }^{2}$ The PSBS database is accessible through the IMF data portal using the web address http://data.imf.org/psbs.

${ }^{3}$ Irwin (2012) presents several examples of such practices.
} 
balances could be financed. These traditional fiscal frameworks did not focus on noncash economic flows and the recording of assets other than cash.

Even today, while governments are often the largest organizational unit in a country, and in control of a large pool of financial and nonfinancial assets and liabilities they often do not report comprehensively on their finances. ${ }^{4}$ Relatively small private sector companies are required to comply with rigid reporting requirements in line with international accounting standards, but governments have not felt the need to impose the same requirements on themselves. Moreover, the narrow focus on the budget of the government has proven to be deficient in capturing all the fiscal risks that governments are exposed to.

The unease with the inadequate way in which governments report their finances has led the IMF to develop the Government Finance Statistics Manual 2001. The manual incorporated for the first time an accrual basis of recording, resulting in an integrated balance sheet approach to compiling and presenting fiscal data. Similarly, the Government Finance Statistic Manual 2014 built on this framework, harmonized it with the International Public Sector Accounting Standards (IPSAS), and elaborated on how to include public corporations in the fiscal framework.

Following the financial crisis, where realizations of contingent liabilities and balance sheet activity led to sharp unanticipated increases in government debt (and, in some cases, also in government assets), the IMF pushed for countries to extend the coverage of fiscal reporting and pay greater attention to fiscal risks. ${ }^{5}$ This led to the development of the Fiscal Transparency Code. The Code (IMF, 2019) introduces and promotes transparency and accountability in the use of all public sector resources and supports government's efforts to strengthen economic governance, policymaking and institution building. The Code expands the coverage of fiscal reporting to the public sector to capture all the fiscal activities and risks that the government is exposed to by not only looking at the operations of governments but also at their stocks of assets and liabilities as reflected in their balance sheets. However, much work remains on improving the coverage of stocks and institutions by many governments (Figure 1 ).

Only a few countries currently undertake the compilation of a PSBS. The PSBS database fills this gap by presenting estimates of these balance sheets for a broad sample of 38 countries. These were compiled on a best efforts' basis using readily available statistical data and financial information from audited financial statements. While the methodology is highly relevant in the current context as discussed above, the data in this working paper generally cover data up to 2016. The database does not cover the current crisis, but work has commenced to update and expand the database. Data for the central and general government generally were sourced from the IMF's Government Finance Statistics (GFS) database. Where these data fail to cover all

\footnotetext{
${ }^{4}$ Gaspar and others (forthcoming) explore the reasons why the production, dissemination and use of information on public sector balance sheets and public wealth met limited enthusiasm around the world.

${ }^{5}$ IMF (2012) discusses in greater detail several such examples.
} 
categories of assets and liabilities, they are complemented by other data reported by statistical authorities at the national level or to other international organizations, or by IMF staff estimates. Data for public corporations are compiled from three main sources: (i) data for the central banks are from the IMF's Monetary and Financial Statistics database; (ii) data for other public corporations were sourced from statistical or government shareholding reports; and (iii) where the latter were not available, a conversion of the financial statements of the largest corporations was used instead. ${ }^{6}$ The sources of country data, as well as country-specific compilation methods were captured in metadata for each country and are published as part of the PSBS database.

Figure 1. Fiscal Transparency Evaluation Scores (Percentage of countries in each level of practice)

\section{Coverage of Stocks}

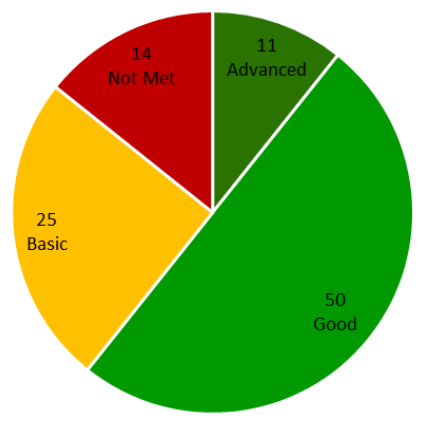

2. Coverage of Institutions

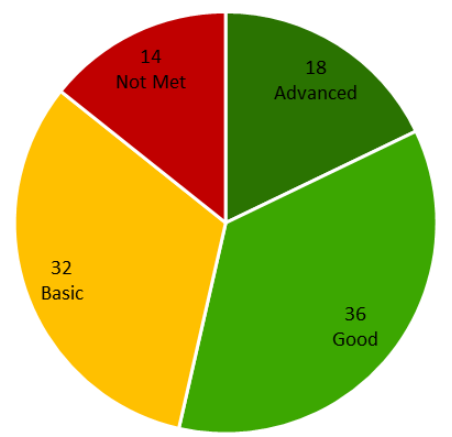

Source: IMF staff estimates.

Notes: Based on data from 28 countries.

Levels of practice for coverage of stocks: cash and deposits, and all debt (basic); all financial assets and liabilities (good); all financial and nonfinancial assets and liabilities, and net worth (advanced).

Levels of practice for coverage of institutions: all central government entities (basic); all general government entities (good); all public sector entities (advanced).

This working paper presents in Section II a broad overview of the PSBS database and describes, for both potential users and compilers of these data, the conceptual framework and methodology underlying the PSBS database. Section III describes the global trends in these data, illustrating the expanded analysis that can be performed with such a dataset. For those interested in compiling PSBS data, Section IV provides practical entry-point guidelines on the compilation, validation, and dissemination of such data. Some aspects of these entry-point guidelines lean themselves to further elaboration in detailed topical follow-up work. The paper concludes with a discussion on the way forward with developing this database.

\footnotetext{
${ }^{6}$ These largest corporations typically cover 80 - 90 percent of all public corporations as measured by their assets.
} 


\section{OVERVIEW OF THE PSBS DATABASE}

\section{A. Coverage of the PSBS database}

The PSBS database presents comprehensive annual balance sheet data for a total of 75 countries and territories at different degrees of institutional coverage (Figure 2 and Table 1). Estimates covering the full public sector are available for 38 countries. These were produced in two different contexts: standalone time series compilation to support the analysis presented in the October 2018 IMF Fiscal Monitor (17 countries); and single-year data compiled as part of Fiscal Transparency Evaluations ( 21 countries). The database is also populated with lower institutional coverage (general government or central government) estimates, derived primarily from authorities' annual data submissions for publication in the IMF's GFS Database. The datasets for countries for which public sector or general government estimates were compiled also included data at lower levels of coverage. Thus, central government can be shown for 74 countries and territories, and general government for $66 .^{7}$

Figure 2. Institutional Coverage of the PSBS Dataset (Largest level of government available for each country and territory)

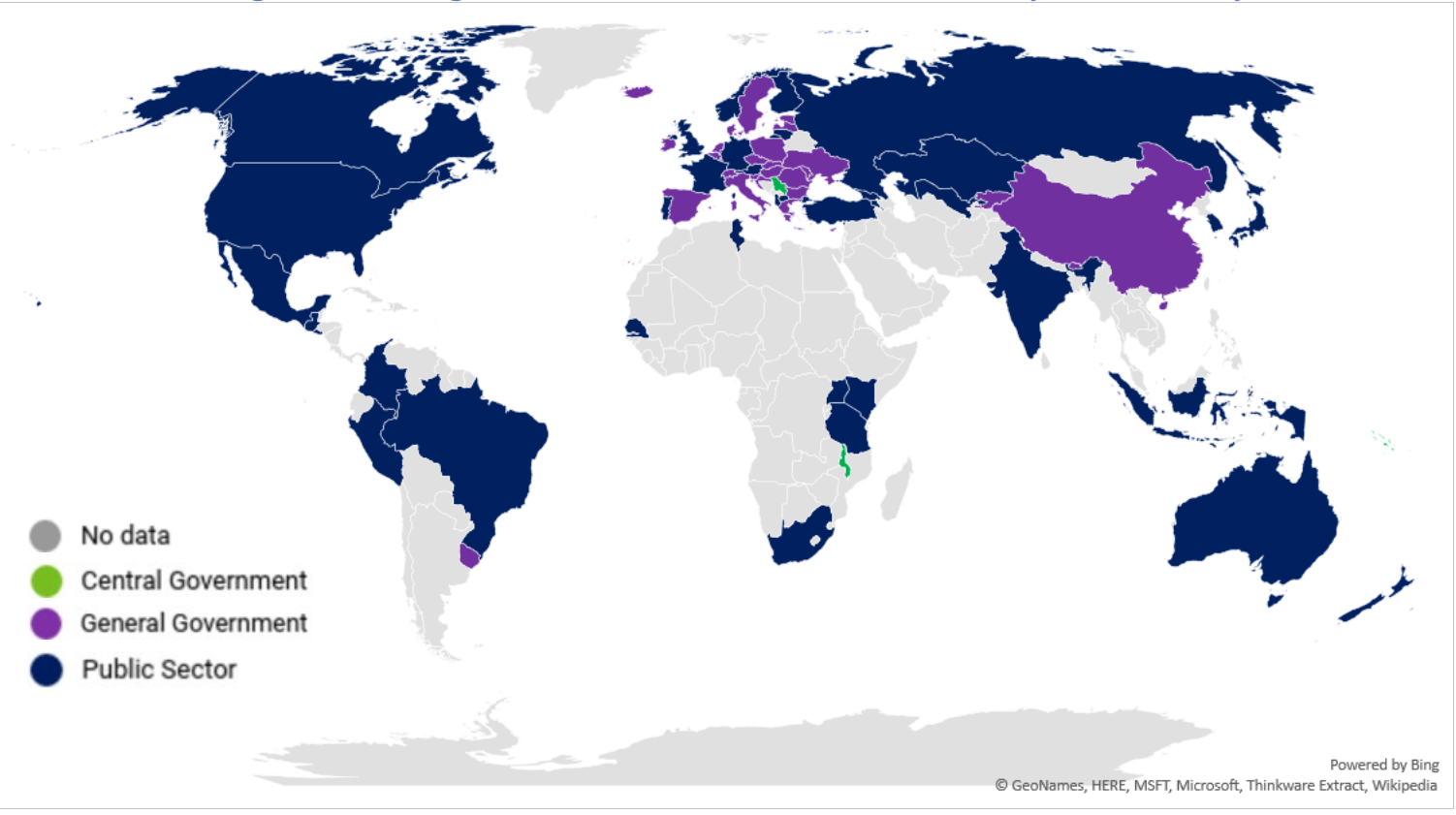

Source: IMF staff.

The database is fairly comprehensive. It covers 91 percent of the world's GDP at the general government level, while the coverage for public sector is close to 63 percent of world's GDP8 (Figure 3). Of the 38 countries with public sector data, 15 are advanced economies, 17 are

\footnotetext{
7 See Appendix I for specifics on country coverage.

${ }^{8}$ Based on the latest available year for each country. For 2016, the coverage is 56 percent of world's GDP.
} 
emerging market economies, and 6 are low income developing countries (Figure 4). Narrowing the scope to general government the database covers data on 66 countries and territories, of which 34 are advanced economies, 24 are emerging market economies, and 8 are low income developing countries. Further narrowing the scope to central government, data on 74 countries are included in the database, of which 34 are advanced, 30 are emerging, and 11 are low income.

Table 1. Public Sector Balance Sheet Database Coverage

\begin{tabular}{|c|c|c|}
\hline \multirow{3}{*}{$\begin{array}{l}\text { Public } \\
\text { Sector } \\
(38)\end{array}$} & $\mathrm{AE}$ & $\begin{array}{l}\text { Australia, Austria*, Canada, Finland, France, Germany, Japan, Korea, Lithuania*, Malta*, } \\
\text { New Zealand, Norway, Portugal*, United Kingdom, United States }\end{array}$ \\
\hline & EM & $\begin{array}{l}\text { Albania, Armenia*, Brazil*, Colombia*, El Salvador, Georgia, Guatemala*, India*, } \\
\text { Indonesia, Kazakhstan, North Macedonia*, Mexico*, Peru*, Russia*, South Africa, Tunisia*, } \\
\text { Turkey* }\end{array}$ \\
\hline & LIDC & The Gambia*, Kenya*, Senegal*, Tanzania*, Uganda*, Uzbekistan* \\
\hline \multirow[t]{3}{*}{$\begin{array}{l}\text { General } \\
\text { Government } \\
\text { (30) }\end{array}$} & $\mathrm{AE}$ & $\begin{array}{l}\text { Belgium, Hong Kong SAR, Cyprus, Czech Republic, Denmark, Estonia, Greece, Iceland, } \\
\text { Ireland, Italy, Latvia, Luxembourg, Netherlands, San Marino, Slovak Republic, Slovenia, } \\
\text { Spain, Sweden, Switzerland }\end{array}$ \\
\hline & EM & Bulgaria, China, Croatia, Hungary, Poland, Romania, Ukraine, Uruguay \\
\hline & LIDC & Bhutan, Kyrgyz Republic, Moldova \\
\hline \multirow{3}{*}{$\begin{array}{l}\text { Central } \\
\text { Government } \\
\text { (7) }\end{array}$} & $\mathrm{AE}$ & \\
\hline & EM & Barbados, Marshall Islands, Micronesia, Palau, Serbia \\
\hline & LIDC & Malawi, Solomon Islands \\
\hline \multicolumn{3}{|c|}{$\begin{array}{l}\text { Note: } A E=\text { advanced economies, EM = emerging markets, LIDC = low income developing economies } \\
\text { * Based on a single year of data, in most cases compiled as part of the Fiscal Transparency Evaluation: Albania, 2013; } \\
\text { Armenia, 2016; Austria, 2015; Brazil, 2014; Colombia, 2016; The Gambia, 2016; Guatemala, 2014; Kenya, 2013; } \\
\text { Lithuania, 2017; North Macedonia, 2016; Malta, 2016; Mexico, 2016; Peru, 2013; Portugal, 2012; Russia, 2012; Senegal, } \\
\text { 2016; Tanzania, 2014; Tunisia, 2013; Turkey, 2013; Uganda, 2015; Uzbekistan, 2016. }\end{array}$} \\
\hline
\end{tabular}

Figure 3. GG and PS Coverage (Share of world GDP)

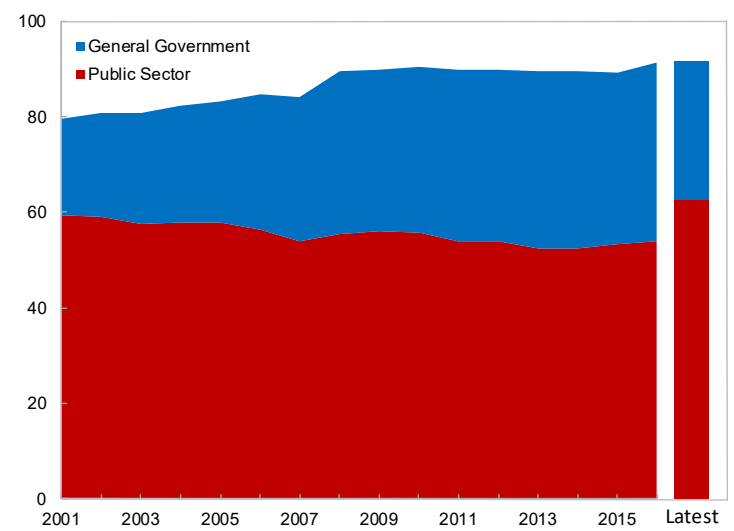

Source: IMF staff estimates.
Figure 4. Coverage by Income Group (Number of countries and territories, latest available year)

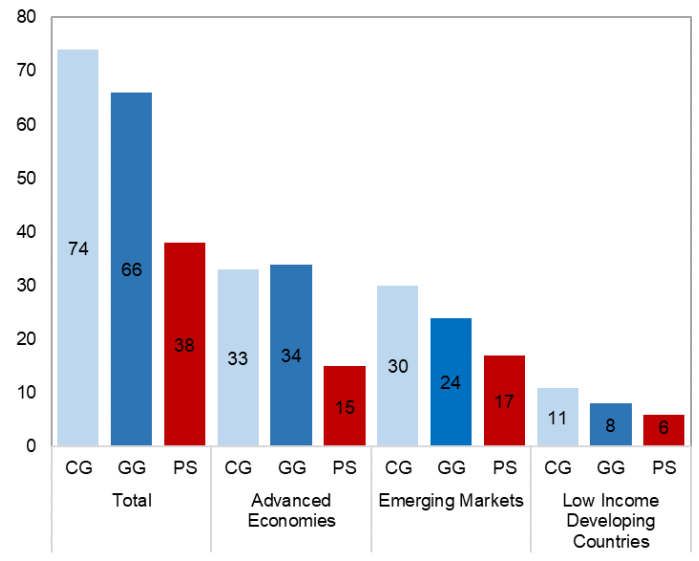

Source: IMF staff estimates. 
Advanced economies tend to have more comprehensive data than other countries. Figure 5 shows the number of countries or territories that disclose different elements of the balance sheet in each intersection of income group and level of government. Reflecting their more advanced statistical systems, the advanced economies generally disclose more elements of the balance sheet than emerging market economies or low-income developing countries. In advanced and emerging market economies, the balance sheet is more comprehensive for general government than central government. This reflects the fact that estimates for nonfinancial assets and pension liabilities are often undertaken in the context of national accounts compilation, which traditionally don't report data for subsectors of general government.

Figure 5. Coverage of Stock Positions by Income Group and Level of Government

(Number of countries and territories)

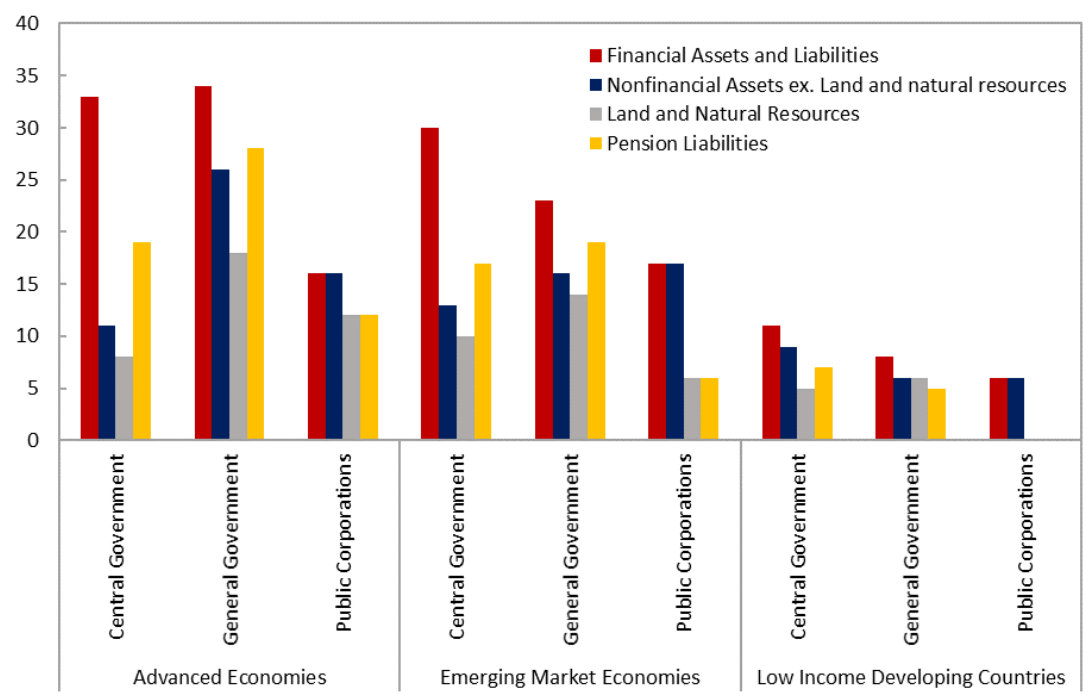

Source: IMF staff estimates.

\section{B. Conceptual Framework}

The PSBS database is compiled using the conceptual framework of the IMF's Government Finance Statistics Manual 2014 (GFSM 2014) (IMF, 2014). As such, it brings together all of the accumulated assets and liabilities that the government controls. It extends the scope of fiscal analysis beyond the standard measures of debt to include all assets, whether financial, infrastructure, or natural resources, as well as liabilities that are rarely included in government debt, such as pensions obligations toward public sector employees. It extends the perimeter of coverage from general government to the entire public sector, bringing in public corporations, including the central bank. Changes in the balance sheet can be explained using the integrated stock-flow framework embodied in the GFSM 2014. This allows the changes in net worth to be decomposed into fiscal deficits, investments, valuation changes, and other changes in the volume of assets and liabilities. 


\section{Coverage of Institutions}

Conceptually, the public sector consists of all resident institutional units that are deemed to be controlled by the government. This includes all general government units (i.e., nonmarket entities), such as departments, agencies, and nonprofit institutions controlled by the government, as well as corporations (i.e., market producers) controlled by a government unit or another public corporation. Control of a corporation is established when the general corporate policy is determined by government. Public corporations comprise government-controlled market producers that operate in both the financial and nonfinancial sector of the economy. Following the GFSM 2014 criteria to delineate market producers from nonmarket producers, the legally incorporated units that operate on a nonmarket basis are reclassified to the general government. These criteria are based on the analysis of whether the corporations provide all or most of their output at economically significant prices or not. ${ }^{9}$

The PSBS database presents the data for the consolidated public sector as well as for its different subsectors, as follows:

- General government, with data for the central government level also available; ${ }^{10}$

- Nonfinancial public corporations; for analytical purposes, natural resource corporations are presented separately from other nonfinancial public corporations; and

- Financial public corporations, split to identify separately the central bank, sovereign wealth funds (where they operate as financial corporations), and other financial public corporations. ${ }^{11}$

Central banks are included in the public sector. Due to their unique role in the economy, they are separately identified in the PSBS database, recognizing the fact that their monetary liabilities (currency on issue) are irredeemable, and have no ongoing financing costs, but are treated as liabilities by convention. The equity liability of the central bank is reported on a book value basis,

\footnotetext{
${ }^{9}$ The GFSM 2014, Chapter 2 presents more detailed guidance on institutional unit and sector classification. Details on specific reclassifications performed in the compilation of PSBS data are described in the country specific database documentation.

${ }^{10}$ Central government data includes social security funds. When these data are not available, they were proxied with, by order of preference, data on central government excluding social security funds, or budgetary central government. The specific choice for each country is available in Appendix I.

${ }^{11}$ The establishment of an SWF raises the issue of whether this fund is classified as part of the general government, as a public corporation, or outside the public sector. The classification of a sovereign wealth fund controlled by government in the general government sector or financial corporation subsectors is determined by the same sectorization principles that apply to any other entity, as described in the GFSM 2014. SWF would be classified as a general government unit if it is simply a passive holder of government's assets or liabilities.
} 
which is the difference between the value of its assets and nonequity liabilities-their net worth is therefore zero.

\section{Coverage of Stocks}

The PSBS database includes all assets (financial and nonfinancial) owned and liabilities owed by the public sector or the relevant subsector at the end of each reporting period. Following the standard approach in macroeconomic statistics, economic ownership rather than legal ownership is used as a reference. Net worth is a balancing item representing the extent to which market values of liabilities are covered by the market value of assets.

The composition of the balance sheet that is used in the analysis is summarized in Table 2, which shows how assets and liabilities are disclosed in the database, broken down by type of asset or financial instrument. ${ }^{12}$ For analytical purposes, financial assets and liabilities are further broken down by currency of denomination and residual maturity, where available.

Table 2. Composition of the Public Sector Balance Sheet

\begin{tabular}{|l|l|}
\hline \multicolumn{1}{|c|}{ ASSETS } & \multicolumn{1}{c|}{ LIABILITIES } \\
\hline Nonfinancial Assets & SDRs \\
\hline Fixed assets & Currency and deposits ${ }^{2}$ \\
\hline Land & Debt securities \\
\hline Mineral and energy resources ${ }^{1}$ & Loans \\
\hline Other nonfinancial assets & Equity and investment fund shares \\
\hline Financial assets & $\begin{array}{l}\text { Insurance, pension, and standardized guarantee } \\
\text { schemes (ISPSG) }\end{array}$ \\
\hline Monetary gold and Special Drawing Rights (SDRs) & Pension entitlements \\
\hline Currency and deposits & Claims of pension funds on pension managers \\
\hline Debt securities & Other ISPSG liabilities \\
\hline Loans & Financial derivatives and employee stock options \\
\hline Equity and investment fund shares & Other accounts payable \\
\hline $\begin{array}{l}\text { Insurance, pension, and standardized guarantee } \\
\text { Schemes }\end{array}$ & \\
\hline Financial derivatives and employee stock options & \\
\hline Other accounts receivable & Net Worth (= Assets - Liabilities) \\
\hline
\end{tabular}

${ }^{1}$ This category includes both "mineral and energy resources" or "permits to use natural resources," as relevant for each country.

${ }^{2}$ Includes bank notes and coins issued. These are normally reflected in the balance sheet of the central bank, but in some cases also the central government's, depending on country-specific arrangements for the issuance of currency. In exceptional cases, countries may allow designated commercial banks to also issue currency under the authorization of the central bank, but this is unusual.

12 The GFSM 2014, Chapter 7 presents definitions and valuation methods for each type/instrument of assets and liabilities. The valuation methods that were used in the analysis for specific types of assets and liabilities are summarized below. 
The PSBS data allow the calculation of several indicators, which are useful from an analytical perspective to measure balance sheet strength, namely: net worth, net financial worth, net liquid assets, and net foreign exchange assets.

In the GFSM 2014 conceptual framework, corporations' liabilities in the form of "equity and investment fund shares" are determined by the value of its shares at current market prices. However, where a public corporation is fully owned by the government or the market value of shares cannot be observed because they do not trade in the market, the value of equity and investment fund shares is calculated as the net asset value of the corporation (i.e. assets minus liabilities other than equity). In these cases, the statistical net worth, calculated as total assets minus total liabilities, is zero. This approach prevents the use of a subsector's net worth as the value of its contribution to the overall public sector net worth. The value of net worth plus shares and equity (often referred to as "own funds") should therefore rather be used to calculate the subsector's contribution to the overall public sector.

The coverage of categories of assets and liabilities in balance sheets that are compiled by statistical authorities vary significantly from country to country. Some categories are often not recognized in the published balance sheets, and the PSBS database has therefore covered these categories by IMF staff estimates, data sources permitting. Most notably, these estimates include: nonfinancial assets - particularly land and mineral and energy resources—and public sector employment-related pension liabilities.

Public sector employment-related pension liabilities refer to pension entitlements of civil servants and public corporation employees under various pension arrangements. These pension liabilities have rarely been included in government's balance sheets although they constitute a contractual obligation of the public sector unit as employer toward its employees. The claims that these public sector employees have are in line with their condition of employment contracts and cannot be amended through subsequent policy changes -the obligation is therefore recognized in the PSBSs. In contrast, some old age benefits may be acquired through other social security arrangements, which are of a contingent nature and therefore recorded differently. These pension arrangements may differ from country to country and even within a country various types of arrangements may exist. Depending on how the arrangement was set up, the impact on the PSBS will be different. Boxes 1 and 2 illustrate how some of these arrangements are organized and recorded; a full discussion can be found in GFSM 2014, Appendix II. 


\section{Box 1. Illustrative Impact of Various Pension Arrangements on PSBS}

Old age adversely affects the welfare of a household by imposing additional demands on their resources or by reducing their income, thereby creating a social risk. Governments organize pension arrangements to protect households against this risk in broadly three different ways, each way reflected differently in PSBSs:

- $\quad$ The pensioner that meets the eligibility criteria (usually comprising of an age and a means criteria) receives benefits without having made any contributions or participating in a scheme. In such cases, the benefits are provided on an "as needed basis; as these benefits are subject to policy changes, no liability for the payment of future benefits is included in the PSBS. These benefits are classified as social assistance benefit expense in government accounts and lead to a redistribution of income. General taxes and other resources of government are used to make transfers to the affected pensioners. The impact of this type of arrangement on the PSBS is limited to a reduction in cash and deposit assets when a benefit payment is made. An example of this type of scheme is the Australian means tested old age pensions.

- The pensioner receives benefits as part of a social security scheme, after having made social contributions during his employment life. No liability for future social security benefits is recognized in the PSBS, as the level of those benefits is subject to policy changes. The finances of these arrangements function similarly to nonlife insurance schemes. Neither the contributions nor the benefits constitute a direct exchange, but rather a contingent exchange. Contributions receivable by government from a large pool of contributors constitute government social insurance revenue. Such revenue may or may not be earmarked for the payment of the social insurance benefit expense when the contingent social risk arises. This type of arrangements is essentially a process of redistribution across a wide section of the population: many individuals contribute resources so that those in need may benefit. The impact of this type of arrangement on the PSBS is again limited to a net change in cash and deposit assets when the contributions and payments are made. An example of this type of the scheme is the US Social Security-it is, a social insurance program that provide retirement, disability, and survivors benefits financed by contributions under the Federal Insurance Contributions Act.

- The pensioner withdraws funds from a notional individual account, after having made contributions (actual or imputed) in his capacity as employee, self-employed or unemployed to a pension scheme to accumulate assets. These contributions are conditions of an employment contract and, as such, establish a contractual liability of the recipient of the contributions toward the contributor and subsequent withdrawals reduce the liability. Government employee pension arrangements are most often organized in this manner. The finances of these arrangements function similarly to life insurance schemes. There is relatively little redistribution among the various households holding similar policies and members of the household can predict with a reasonable degree of certainty what they will receive and when. These pension schemes can be arranged as either a defined contribution or a defined benefit scheme (see Box 2). The impact on the PSBS depends on who operates the scheme. If government is the operator of the scheme, the impact of this type of arrangement on the PSBS is that the pension contributions to these schemes are recorded as an increase in cash and the incurrence of a pension liability for the operator of the scheme. Whenever the contributor draws on the benefits of the scheme, the transaction constitutes a reduction in these pension liabilities of the operator of the scheme and a reduction in currency and deposits. An example of this type of scheme is the South African Government Employees Pension Fund. If the operator of the scheme is in the private sector the impact on the PSBS is different. The government is primarily liable for making the contributions to the scheme on behalf of its employees, which result in a reduction in cash and deposit assets of government when the pension contribution is made as part of the compensation of employees' expense. The government accounts will not show any pension liabilities toward the household sector in this case, because these obligations are reflected in the accounts of the private operator of the scheme. Provident funds are often arranged in this manner. However, in both the case of public sector units or private sector units operating defined benefit schemes, the government as employer could continue to determine the terms of the pension scheme and therefore retains the responsibility for any deficit in funding, (or the right to retain any excess funding). In this case the PSBS is affected in an additional manner. Because the employer is responsible for any deficit on the pension fund, the pension fund has a claim on the government as pension manager. Such a claim is shown under the liability claims of pension funds on pension managers. Conversely if the employer has a claim on the pension fund for excess contributions, the employer records this claim as a financial asset.

Source: Staff and GFSM 2014 


\section{Box 2. Funding Arrangements by type of Employment-Related Pension Schemes}

When governments arrange pension schemes that are specific for government employees (including those cases where they receive pensions from the general social security scheme, but under conditions that are different from those of the general population), those schemes are considered employment-related pension schemes. Various types of such schemes exist and the manner in which they operate influence the way the respective transactions and stock positions are recorded in GFS and the PSBS. Knowledge of how the differences in these schemes impact the balance sheet should be considered when analyzing and comparing balance sheet data across countries and regions.

\section{There are three types of employment-related pension schemes:}

- Nonautonomous pension schemes are an integral part of the employer operating the scheme. These do not meet the criteria to be separate institutional units and all the operations of the scheme are therefore reported as part of the unit that operates the scheme.

- Autonomous pension funds are separate institutional units that operate independently in the financial corporations sector. They could either be a public financial corporation or a private financial corporation depending on who is in control of the entity.

- A scheme managed by an insurance enterprise or pension fund on behalf of the employer-entities are also regarded as a financial corporation.

If a government operates a nonautonomous pension scheme all the assets and liabilities of the pension scheme will be reflected on the accounts of the government unit that controls the scheme. Autonomous pension funds under the control of the government will be classified as public financial corporations and will display all the assets and liabilities of the pension scheme as part of their balance sheet. Similarly, if a scheme is managed by an insurance enterprise on behalf of the government as employer, the control of the enterprise will determine whether they are classified in the private financial corporations sector or the public financial corporations sector.

\section{These pension schemes could operate as a defined-contribution scheme or as a defined benefit scheme:}

- A defined-contribution scheme is one where the benefits are determined by the actual contributions made to the scheme, and the investment income and holding gains and losses earned on these and previous contributions. These pension schemes are by definition net worth neutral because their assets equal their liabilities.

- Under a defined-benefit scheme the ultimate benefit is calculated by means of a formula embodied in the terms of the scheme. These benefits are usually determined in terms of the conditions of employment undertakings made by the employer toward their employees.

The recording of pension schemes is further impacted by the extent to which they are funded. By definition, defined-contribution schemes are deemed to be fully funded., For defined-benefit schemes, various options exist:

- A scheme is funded if contributions are held in a segregated fund (reserve), from which future benefits will be payable. Therefore, the cash in the pension reserve account will increase when contributions are made with a corresponding increase in pension liabilities, while pension benefit payments will reduce the reserve account with a corresponding decrease in pension liabilities. If the fund is sufficient to finance the present value of the future benefits payable, the scheme is fully funded. If the fund is insufficient to finance the net present value of the future benefits payable, it is underfunded, and when the reserve is more than sufficient it is overfunded.

- A scheme is unfunded when contributions are not held in a segregated fund (reserve). Therefore, pension contributions will increase the general resources of currency and deposits, with a corresponding increase in pension liabilities. Similarly, these general resources will reduce when pension benefit payments are made with a corresponding decrease in pension liabilities. By definition, unfunded schemes cannot be considered a separate institutional unit.

Source: GFSM 2014. 
When these types of assets and liabilities could not be estimated, the relevant main aggregates of the balance sheet items were marked as "not available." To ensure a correct cross-country comparability, alternative main aggregates were calculated, and disclosed as separate indicators, as follows:

- Nonfinancial assets, excluding land and mineral and energy resources;

- Total assets, excluding land and mineral and energy resources;

- Liabilities, excluding pension-related liabilities (pension entitlements and claims of pension funds on pension managers);

- Net financial worth, excluding pension liabilities; and

- Net worth, excluding land, mineral and energy resources, and pension liabilities.

\section{Coverage of Flows}

The database includes the main flow aggregates, separating transactions and other economic flows. It also includes some more detailed categories of flows, which are directly related to assets and liabilities, such as interest receivable and payable, and rent, as well as those related to the relationship between government and public corporations-such as dividends, subsidies, or capital transfers payable and receivable.

Transactions correspond to interactions between units by mutual agreement or through the operation of the law. They are presented in the PSBS database in an abbreviated statement of operations, with the following main aggregates disclosed:

- Revenue and expense - which are transactions that increase or decrease net worth, respectively;

- Expenditure is the sum of expense and net acquisition of nonfinancial assets; and

- Net acquisition (acquisitions less disposals) of both nonfinancial and financial assets, and net incurrence (incurrence less repayment) of liabilities-which are transactions that change the composition of assets and liabilities but not net worth.

These aggregates allow the calculation of the following balancing items:

- Net operating balance (NOB) is the difference between revenue and expense, with the latter including consumption of fixed capital; and

- Net lending or borrowing (NLB) is the difference between revenue and expenditure; ${ }^{13}$ NLB is often also referred to as the "fiscal balance" or the "deficit/surplus."

\footnotetext{
${ }^{13}$ This corresponds to the "above-the-line" approach for calculating net lending or borrowing. Since doubleentry recording is used for recording all flows in the GFSM 2014 conceptual framework, that balancing item can also be calculated from "below-the-line," as the difference between the net acquisition of financial assets and the net incurrence of liabilities.
} 
Other economic flows (OEFs) result from revaluations (changes in prices and exchange rates) and other changes in the volume of assets and liabilities. The latter category can include: the economic recognition or derecognition of produced assets, such as valuables (or public monuments, if these are included in the balance sheet); entry and exit from the asset boundary of natural resources, as a result of changes in prices that make the exploitation of those resources economically viable or unviable; destruction of assets from large-scale, discrete events, such as earthquakes, volcanic eruptions, floods, or other natural disasters; or the reclassification of units (for example, a government unit that is transformed into a public corporation).

The database allows a full integration of stocks and flows. Therefore, the stock at the end of the reference period corresponds to the sum of the stock at the beginning of the reference period plus transactions and OEFs occurring during the reference period. For the net worth indicator, this accounting identity can be illustrated as follows:

$N W_{t}=N W_{t-1}+$ Transactions affecting NW + Changes in NW due to OEFs

that is, $N W_{t}=N W_{t-1}+N O B_{t}+O E F_{t}$

By the definitions for net operating balance and net lending/borrowing, these can be denoted as follows:

$N O B_{t}=R E V_{t}-E X P_{t}$ and $N L B_{t}=R E V_{t}-\left(E X P_{t}+I N V_{t}\right)$,

in which REV corresponds to revenue, EXP corresponds to expense, and INV corresponds to net investment in nonfinancial assets.

This allows us to rearrange equation (1) as follows:

$N W_{t}-N W_{t-1}=N L B_{t}+I N V_{t}+O E F_{t}$

This is the approach followed in the analysis of the evolution of balance sheets in Sections III.A and III.B, particularly in Figures 7 and 9, where the change in net worth is explained by the sum of the fiscal balance, investment, and valuation effects.

\section{Data Sources and Methodology}

PSBSs timeseries were estimated for a set of 17 countries, bringing together data from the IMF's Government Finance Statistics and Monetary and Financial Statistics databases, as well as publicly available information on public corporations. In some cases, these were sourced from aggregate consolidated reports on state-owned entities compiled by the authorities or from the financial statements from countries' largest public corporations. In addition, PSBS standalone data for 21 countries using the results of the Fiscal Transparency Evaluations were used to develop the database. Staff have drawn on publicly available data to fill in other gaps in the data, and have prepared estimates of infrastructure, natural resources assets, and public sector 
pension liabilities where these are not otherwise publicly available or where available data were not consistent with the PSBS methodology.

This section provides additional details on the main data sources and methodology used in this exercise. Country-specific notes were also prepared for the 17 countries and are available at the metadata section of the online PSBS database. ${ }^{14}$

\section{Data Sources}

Data for the central and general government generally replicate data reported by country authorities in the IMF's Government Finance Statistics (GFS) database. Where these data fail to cover all categories of assets and liabilities listed above, they are complemented by other data reported by statistical authorities at the national level or other international organizations, such as Eurostat or the Organisation of Economic Co-operation and Development (OECD). Where data on fixed assets are not readily available, they are sourced from the IMF's capital stock database (IMF 2017). Any remaining data gaps are addressed, where possible, through IMF staff estimates (see the "Methodology" section).

Data for the central bank generally replicate stock data reported by country authorities in the IMF's Monetary and Financial Statistics database through the standardized report forms. For transactions and other economic flow data, and for those countries that do not submit standardized report forms, data are compiled through the conversion of the central banks' financial statements to the PSBS database template.

Data sources for other public corporations are country-specific and are captured in countryspecific database notes. The preferred data sources are statistical estimates produced by country authorities for the aggregate subsector, often compiled as a component of the sectoral accounts. Where these are not available, IMF staff estimates (either calculated specifically for PSBS database or from fiscal transparency evaluations) are used. In these estimates, aggregate financial statements' data from state-owned enterprises ownership or annual reports (adjusted for unit reclassifications) are converted to the PSBS database template. When aggregate data are not available, the conversion of individual financial statements for the major state-owned enterprises is used. The latter option considers materiality: a sample of the largest public corporations, representing a significant share of total public corporation assets (covering about

\footnotetext{
${ }^{14}$ For other countries, i.e., those for which the database includes only central or general government data drawn from the IMF's GFS database, no country specific notes were prepared. Nevertheless, details can be consulted in the metadata of that database, available at http://data.imf.org/regular.aspx?key=60950584
} 
80-90 percent of the total sector) is used and the aggregate result of the financial statements' conversion grossed up to account for the non-sample units. ${ }^{15}$

The public sector data are calculated by aggregating the estimates for general government, nonfinancial public corporations, and financial public corporations, and by identifying and consolidating (or eliminating) the most significant cross-holdings of assets and liabilities or intrapublic sector transactions. ${ }^{16} \mathrm{~A}$ non-exhaustive list of the most relevant items identified for consolidation in the public sector includes:

- General government units' deposits at the central bank or other public banks;

- Central bank and other public corporations' holdings of securities issued by government units;

- General government units' equity stakes in public corporations;

- Loans provided by general government units to public corporations;

- Loans provided by public banks to government units or other public corporations;

- Property income such as interest and dividends paid or received on the aforementioned items; and

- Subsidies and other capital transfers provided by government units to public corporations.

\section{Valuation of Assets and Liabilities}

Assets and liabilities could be valued through different methods (see Box 3). In accordance with the GFSM 2014 guidelines, assets and liabilities are valued at market value, where possible. This is normally the case for assets and liabilities in the form of debt securities and equity of listed corporations, whose values can be observed in financial markets. ${ }^{17}$ Other financial assets and liabilities are often reported at nominal value, which serves as a proxy for market value in cases where financial instruments are not traded.

\footnotetext{
15 Because of source data limitations, data for public corporations were in most cases limited to those corporations under control of the central government. Data for public corporations under the control of state and local governments were generally not available in aggregate formats. The factor by which data were grossed up was derived from the weight of sample units' assets relative to the assets of all corporations, available for example in shareholding reports or other comprehensive reports.

16 These eliminations do not change the balancing items of the balance sheet or the statement of operations, but have an influence on the levels of assets and liabilities or revenue and expense reported by the public sector.

${ }^{17}$ Because of the lack of source data, for some countries the PSBS database presents debt securities at valuations other than market, such as nominal or face value (the latter corresponding to the amount to be paid at maturity).
} 
Where market values are not available for produced nonfinancial assets such as fixed assets, inventories, and valuables, they are usually reported on a written-down (or depreciated) replacement cost.

\section{Box 3. Valuation Methods for Assets and Liabilities}

Market prices: refer to current exchange value, that is the value at which assets/liabilities are exchanged or else could be exchanged for cash on the reporting date-this is the main valuation method used in the statistical basis of reporting.

Fair values: refer to the amount for which an asset could be exchanged, or a liability settled between knowledgeable, willing parties in an arm's length transaction-this is the valuation method often used for traded goods and instruments in accounting standards. It is akin to market value.

Nominal value: refers to the amount that the debtor owes to the creditor at any moment in time. It reflects the value of the instrument at creation and subsequent economic flows such as transactions (interest and principle payments) and valuation changes such as exchange rate changes but excludes market price changes. (Should market price changes be included, the price will represent a market value.)

Historic cost: refers to the cost at the time of acquisition but could sometimes also reflect occasional revaluations.

Face value: refers to the undiscounted amount of principal to be repaid at maturity.

Written-down replacement cost: refers to the current acquisition price of an equivalent new asset minus the accumulated consumption of fixed capital, amortization, or depletion.

Book value: refers to the value recorded in an entities records-it may have different meanings because their values are influenced by accounting standards, rules and policies.

Source: GFSM 2014.

Nonfinancial assets also include nonproduced assets such as mineral and energy resources and land, whose market value can be approximated by the net present value of the future economic benefits expected from such assets. Land includes land under buildings or other structures as well as stewardship land like that where national parks or other heritage sites are located. Because of the underlying difficulties in valuing such stewardship land, or historical heritage buildings, national estimates of nonfinancial assets normally do not include an estimation for these types of assets. ${ }^{18}$ In the absence of any alternative data sources for these estimations, the PSBS database does not attempt to value them.

Public corporations' assets and liabilities are generally reported based on fair value, following accounting standards such as International Financial Reporting Standards. However, the equity of these corporations, both in their balance sheets and as assets of the government, is often reported at its book value. The equity value of public corporations in the PSBS database is set

\footnotetext{
${ }^{18}$ As discussed in Bova and others 2013, because of their nature, location, or attached regulations, they may not be sellable and therefore are excluded from the governments' balance sheets, or valued at one unit of local currency, even though they may create revenue (for example, tourism receipts) and generate maintenance costs.
} 
equal to their net asset value. This includes reserves, adjusted for provisions and deferred tax assets, which are not recognized in macroeconomic statistics. Because of data limitations, in some cases no adjustment is done to reflect the difference between the book and market values of listed shares.

\section{Methodology Used to Estimate Specific Categories of Assets and Liabilities}

Fixed Assets. Existing government estimates for fixed assets other than historical/heritage assets are used where available. In a few cases, these estimates are based on detailed asset management registers, but more often, they rely on authorities' application of the perpetual inventory method on detailed asset-level information. With this method, the value of the stock is based on estimates of acquisitions and disposals that have been accumulated (after deduction of the accumulated consumption of fixed capital, amortization, or depletion) and revalued over a long enough period to cover the acquisition of all assets in the category. However, data are often missing or poorly reported, with serious valuation issues (Bova and others 2013).

Where there are gaps, estimates of fixed assets (for example, infrastructure, buildings) are provided based on the IMF's capital stock and investment database (IMF 2017), which includes estimates for the public capital stock also compiled through the perpetual inventory method, and calculated for the overall level of investment, rather than for detailed asset-level investment. ${ }^{19}$

Mineral and Energy Resources. Country estimates for mineral and energy resources are often based on various estimation techniques. Few countries disseminate such data due to the complexity of these techniques and the fact that they are highly sensitive to the discount rate used to bring future cash flows into present values. To attain consistency, the PSBS database follows the GFSM 2014 valuation guidelines to estimate these values. Estimates for the stock of mineral and energy resources in the PSBS database correspond to the net present value of the expected pretax cash flows resulting from their commercial exploitation. Sources and methods for these estimates differ by type of commodity, and the choice of estimation method was largely determined by the availability of source data, and attempts to consider country-specific economic conditions in these estimations. ${ }^{20}$

The value of stocks of oil and gas were estimated using the following data sources: (1.1) production over the lifetime of the asset, from the Rystad database (Rystad Energy 2018); (1.2) current and forward prices (in US dollars) from World Economic Outlook (WEO) available at the

\footnotetext{
${ }^{19}$ A detailed description of the sources and methods of the capital stock and investment database can be found at https://www.imf.org/external/np/fad/publicinvestment/data/info122216.pdf.

20 PSBS database estimates differ from the World Bank's The Changing Wealth of Nations 2018 because the World Bank uses a discount rate of 4 percent for all countries and constant value data for prices, whereas the PSBS database uses different vintages of commodity-specific prices from WEO reports.
} 
end of the reference year; (1.3) costs of production (in US dollars), from the Rystad database; and (1.4) exchange rates, from WEO forecasts available at the end of the reference year.

The first three sources (sources 1.1,1.2, and 1.3) were used to calculate future US dollar cash flows over an 85-year horizon (for years beyond those for which WEO forward prices are available, it was assumed that prices remain constant at the latest forward price). These US dollar cash flows were converted to domestic currency using the WEO exchange rate forecasts (source 1.4). The net present value of the domestic currency cash flows was calculated using a discount rate equivalent to the average (2000-22) long-term (10-year) government bond yields in WEO plus a risk factor ( 1 percentage point for advanced economies, 3 percentage points for emerging economies, 6 percentage points for low-income developing countries). When government bond yields were not available from the WEO, the central bank policy rate plus 5 percentage points was used.

The value of stocks of coal, metals, and other minerals were estimated using the following data sources: (2.1) estimates (in constant 2014 US\$ prices), from the World Bank's The Changing Wealth of Nations 2018 (World Bank 2018); (2.2) United States Geological Survey data on 2016 reserves and 2014-16 production by commodity and by country (Wilburn, Bleiwas, and Karl 2016), where available; (2.3) prices (in US\$) from WEO commodity prices for 2000-16; and (2.4) exchange rates, from the current vintage of WEO exchange rates.

Estimates for 2015 and 2016 are based on the changes in reserves in those years, for those commodities for which reserve data are available (source 2.2). Where these are not available (usually cases where reserves for a particular commodity are relatively small), the assumption was that the value of the stocks is unchanged from 2014 onward. The obtained estimates based on the constant 2014 US\$ prices were converted to current US\$ prices using the price index obtained through WEO commodity prices (source 2.3), and subsequently converted to domestic currency using WEO exchange rates (source 2.4).

For countries where subsoil assets can be owned by units other than government, the calculated estimates were prorated using alternative (country-specific) indicators on ownership of land under which the mineral and energy resources lie. Where such country-specific adjustments occurred, it is revealed in the database documentation.

Pension Liabilities. Public sector pension entitlements are the claims that current and past public sector employees hold against their employers - they represent contractual payments that are established as part of the compensation agreement and must be paid, even in the event of future policy changes (representing accrued-to-date entitlements of existing beneficiaries). It is important to note that these employment-related pension liabilities exclude implicit obligations 
to households under general social security arrangements, as these are potentially subject to policy changes (also see Box 1 and 2). ${ }^{21}$

The ideal data source for the employment-related pension liabilities are estimates produced by the country authorities, disclosed in the government's financial statements, in statistical estimates of the sectoral accounts balance sheets, or in supplementary tables on pensions (as is the case for most EU members). ${ }^{22}$

When authorities' estimates are not available, an estimate is produced using a model developed by IMF staff to calculate the accrued-to-date pension entitlements of civil servants and other public sector employees. This model uses actuarial projections of pension expenditure of these employment-related pension schemes. ${ }^{23}$ The estimate of the accrued benefit assumes that the share of the benefit accrued declines with age: in 2015, from 100 percent for those ages 55 and older to 0 for those ages 25 and younger. The population covered by the pension system is assumed to match the structure of the overall population (projections for population use the 2017 UN World Population Prospects-United Nations 2017). The discount rate is assumed to be 1 percentage point above the rate of GDP growth. ${ }^{24}$

Where the aforementioned estimates are available for only a single year because of data limitations, it is assumed that the entitlements as percentage of GDP remain constant over time.

\section{Maturity and Currency Breakdowns}

Where the national data sources include no breakdowns of financial assets and liabilities by maturity and currency, these breakdowns are estimated by IMF staff as follows:

- Liquid assets include "currency and deposits" and "other accounts receivable," while shortterm liabilities are defined as the sum of "currency and deposits," "other accounts payable," and "current debt" (debt securities and loans issued with less than one-year maturity, and long-term debt securities and loans, with a remaining maturity of less than one year).

- The current and noncurrent breakdown of debt securities and loans is obtained through three sources: World Bank's Quarterly Public Sector Debt database, Eurostat, and the

\footnotetext{
${ }^{21}$ Expense for social security benefits payable to households are instead picked up in the intertemporal analysis, as they are embodied in future expenditure.

${ }^{22}$ See https://ec.europa.eu/eurostat/en/web/pensions/information-member-states for details on these tables.

23 If no actuarial projections are available, they are built using current year (2015) pension spending of those pension schemes in percent of GDP, and they assume it grows in line with the old age dependency ratio (this is consistent with a naïve projection model under which the benefit ratio and pension eligibility remain constant over time).

24 This difference of 1 percentage point corresponds to the average observed in the advanced economies over the past 25 years (Escolano 2010; Turner and Spinelli 2012).
}

CInternational Monetary Fund. Not for Redistribution 
Dealogic database on debt securities. Repayments of outstanding IMF loans (where applicable) in the year after the reference period are subtracted from the short-term loans.

- Foreign and domestic currency breakdowns of the debt securities are extracted from the Dealogic database and general government gross debt in foreign currency from the WEO database is used as a proxy of the total liabilities in foreign currency. These data are crosschecked against the outstanding amount of IMF loans (denominated in special drawing rights, SDRs, that is, foreign currency).

\section{GLOBAL TRENDS AND APPLICATION IN FISCAL ANALYSIS}

\section{A. The Evolution of Public Sector Balance Sheets Over Time}

Public sector balance sheets expanded during the global financial crisis, while net worth declined sharply. In the 17 countries for which full PSBS time series data have been compiled, liabilities increased by around 39 percentage points of GDP between 2007 and 2016 . However, a concomitant expansion of public sector assets occurred, with assets other than land and natural resources increasing by 22 percentage points of GDP during 2007-09 in the immediate wake of the crisis, partly because of financial sector interventions; in subsequent years, these assets retreated slightly to remain 14 percentage points of GDP above pre-crisis levels. ${ }^{25}$ Both sides of the PSBS remain significantly larger than they were pre-crisis (Figure 6, panel 1).

Net worth remains well below pre-crisis levels, even as fiscal deficits have been reigned in. Overall, public sector net financial worth deteriorated by US\$ 11 trillion or 28 percentage points of GDP during the post-crisis decade, with a modest decline continuing even in the later years (Figure 6, panel 3). Net worth declined by a similar, though slightly lower 25 percentage points of GDP, with the difference attributable to public investment. This average marks a wide dispersion, with net worth declining by as much as 49 percentage points of GDP in the United Kingdom, while increasing by 167 percentage points of GDP in Norway, much of it because of strong valuation gains from its equity holdings. While fiscal deficits in the advanced economies most affected by the crisis have largely been brought back to moderate levels (see April 2018 Fiscal Monitor), the deterioration in net worth caused by the crisis still needs to be addressed. Applying this analysis to the full balance sheet, i.e., adding land and natural resources as well as pension liabilities (Figure 6, panels 2 and 4) doesn't change the overall trend, but introduces some

\footnotetext{
${ }^{25}$ Examples of financial sector interventions with impact on the public sector balance sheet include: reclassification of previously private banks into the public sector (e.g., the reclassification of Fannie Mae and Freddie Mac expanded the United States public sector assets by US\$ 5 trillion; the reclassification of Lloyds and the Royal Bank of Scotland expanded the United Kingdom's public sector assets by US\$ 1 trillion), government acquisition of stocks of nonperforming loans, and quantitative easing by central banks.
} 
volatility, primarily due to changes in prices of those assets (in particular, natural resources were affected by changes in commodity prices) and the sensitivity of estimates to discount rates.

Figure 6. Public Sector Balance Sheets, 2000-16

(Weighted average of 17 countries, percent of GDP)

1. Assets and Liabilities (excluding land,

2. Assets and Liabilities natural resources, and pension liabilities)

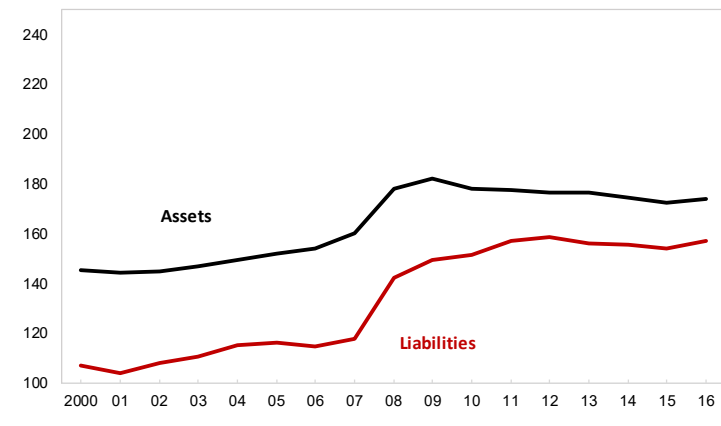

3. Net (Financial) Worth (excluding land, natural resources, and pension liabilities)

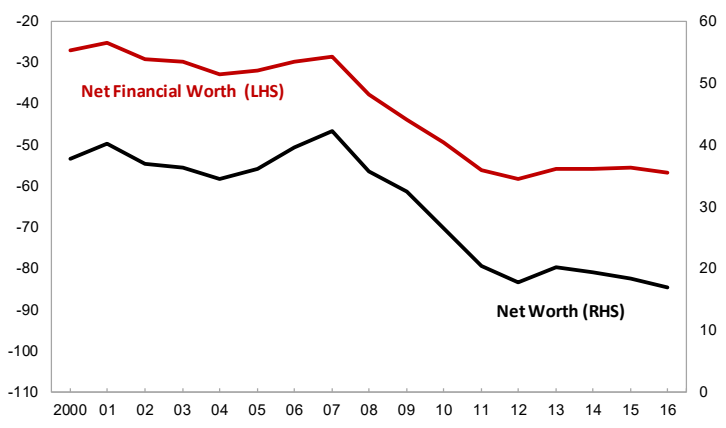

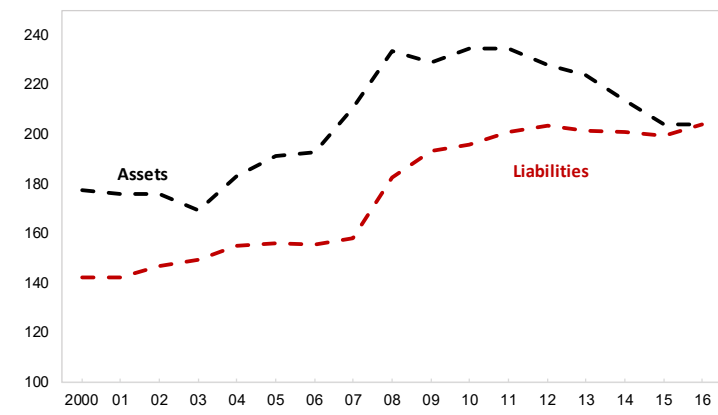

4. Net (Financial) Worth

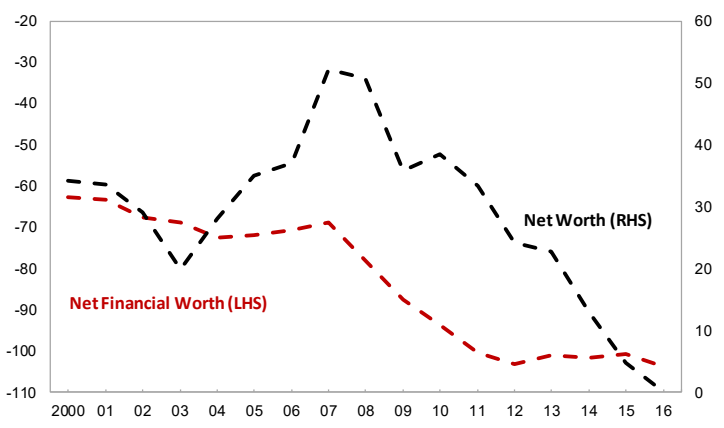

Source: IMF staff estimates.

Notes: Where PSBS estimates have not been compiled for the full-time series, it was assumed that main aggregates as percentage of GDP remain constant over time, at the level of the closest year for which data are available. Overall trends are largely determined by countries with higher weight, for which a full time series is available.

For the 17 countries with public sector time series data, a decomposition of net worth developments shows the relative roles of debt accumulation, public investment, operations in the public corporation sector, and valuation changes. Figure 7 (panel 1) decomposes the increase in net worth prior to the global financial crisis, which went from 38 percent of GDP in 2000 to 42 percent in 2007. Positive valuation changes of around 41 percent of GDP and public investment (7 percent of GDP) were the biggest contributors to the overall increase in net worth, more than offsetting the negative impact of fiscal deficits, estimated at 36 percent of GDP.

The post-crisis deterioration in public wealth was driven by deficits, but balance sheet effects significantly cushioned the decline. Among these countries, net worth fell from 42 percent of GDP in 2007 to 17 percent in 2016 (Figure 7, panel 2). 
Figure 7. Decomposition of Changes in Net Worth

(Weighted average of 17 countries, percent of GDP)

1. 2000-06 (expressed as percent of 2007 GDP)

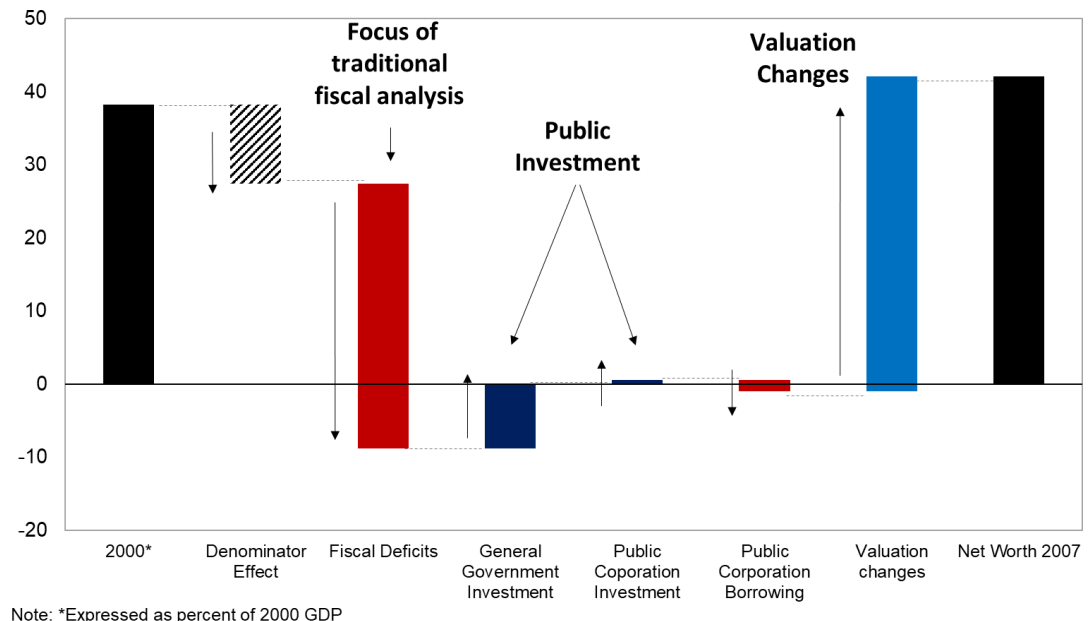

2. 2007-16 (expressed as percent of 2016 GDP)

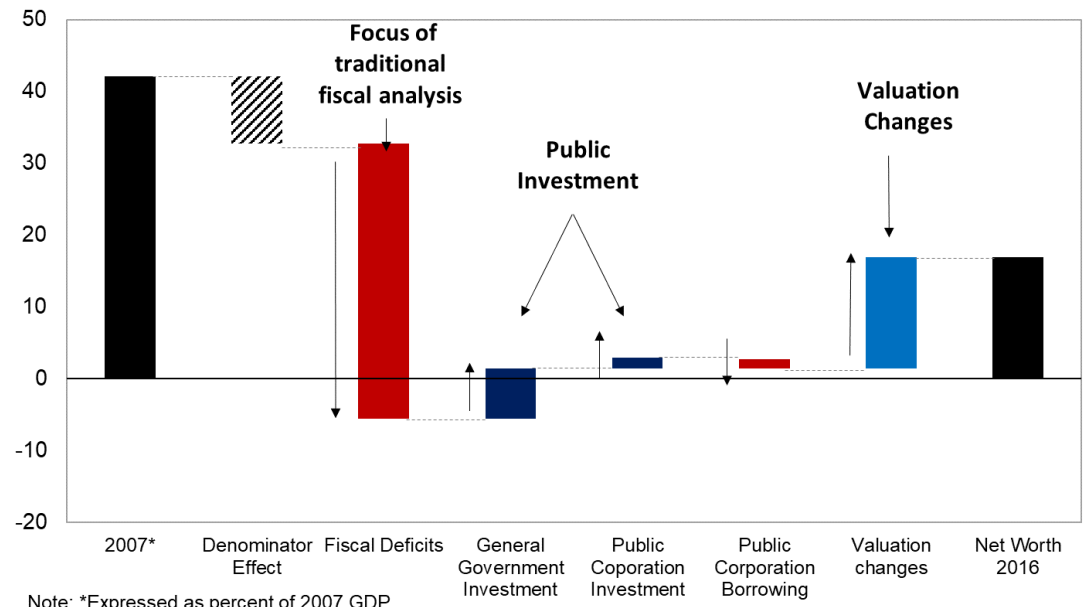

Source: IMF staff estimates.

Note: The data exclude land and natural resource assets and pension liabilities.

Fiscal deficits were the largest factor, contributing 38 percentage points of GDP to the overall decline. Together with the 9 percentage points of GDP denominator effect, net worth dips into negative territory. ${ }^{26}$ However, some of the deficits were used to invest rather than to consume, raising net worth by some 8 percentage points of GDP. While valuations fell during the crisis reflecting falling asset prices, they rebounded in subsequent years, adding another 16

\footnotetext{
26 This denominator effect displays the impact of moving from 2007 to 2016 GDP in the denominator. The 2007 bar is expressed in percent of 2007 GDP, while all other bars are expressed in 2016 GDP.
} 
percentage points of GDP to net worth. Such large balance sheet effects are common across countries and emphasize the usefulness of a PSBS approach.

The contribution of public corporations to the public sector net worth, measured by their equity value (a liability to the corporations' owners, including the government), is sizeable, averaging around 10 percent of GDP in 2016. This is a significant expansion from the contribution at the start of the time series (Figure 8). Nonfinancial corporations contribute in average 2 percentage points more than financial corporations. This difference declined slightly in the years immediately after the main financial sector interventions but reverted to the original trend once some of the larger nationalized financial institutions (primarily Lloyds, in the United Kingdom) were reprivatized.

Figure 8. Equity Liabilities of Public Corporations, 2016 (Weighted average of 17 countries, percent of GDP)

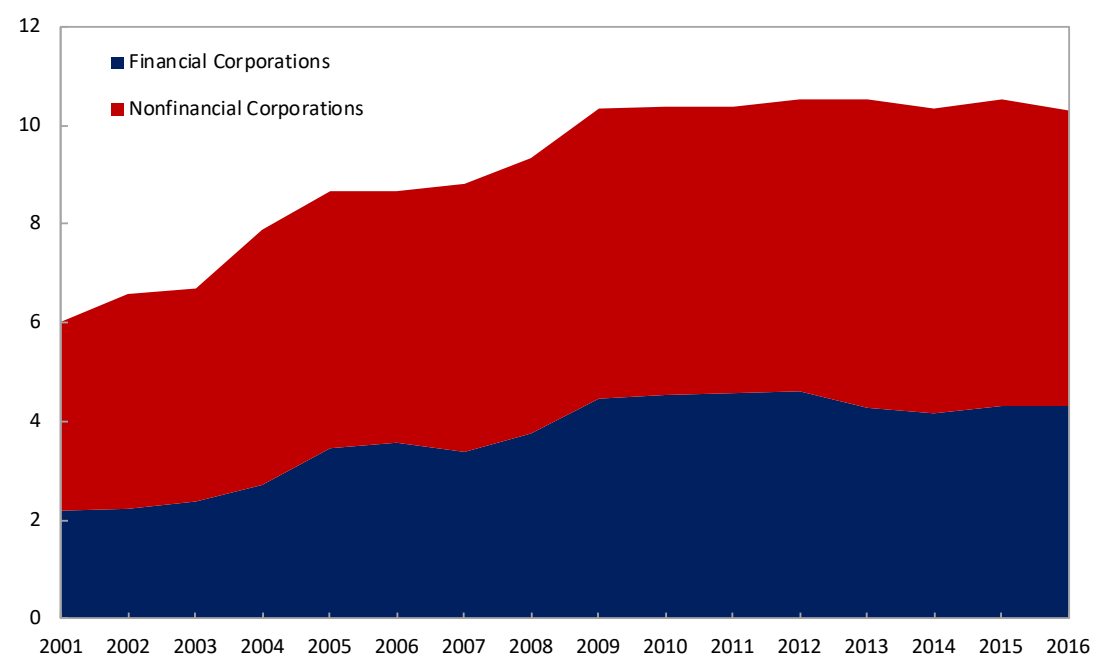

Source: IMF staff estimates.

Note: Data sources permitting, equity liabilities of corporations with shares traded in the market are at market value; for other corporations or when market valuation are not available, they are at book value (see Sections II.B, Coverage of Stocks and II.C, Valuation of Assets and Liabilities).

\section{B. Using Public Sector Balance Sheets in Fiscal Analysis}

\section{Single Country Analysis: The Example of Australia}

An analysis of the PSBS of Australia provides an example of the added richness of the integrated flow and stock analysis that the balance sheet approach provides. ${ }^{27}$ Table 3 presents the public

\footnotetext{
27 Other examples can be found in the October 2018 Fiscal Monitor, and related country-specific working papers including for Indonesia (El Rayess et. al., 2019), Finland (Brede and Henn, 2018), Norway (Cabezon and Henn, 2018)., United States (Gonguet et. al., 2019).
} 
sector balance sheet of Australia for a single period (end-2016), as available in the PSBS database. Similar tables can be produced for each subsector's full time series.

Table 3. Australia: Public Sector Balance Sheet, 2016 (Percent of GDP)

\begin{tabular}{|c|c|c|c|c|c|c|}
\hline & CG & GG & NFPC & FPC & $\begin{array}{l}\text { Public } \\
\text { Sector }\end{array}$ & Cons. \\
\hline \multicolumn{7}{|l|}{ BALANCE SHEET } \\
\hline Total assets & NA & 285.8 & 30.2 & 33.7 & 309.3 & -40.5 \\
\hline Nonfinancial assets & NA & 236.3 & 28.2 & 0.1 & 264.6 & 0.0 \\
\hline Fixed assets & 8.0 & 49.8 & 28.0 & 0.1 & 77.9 & 0.0 \\
\hline Land & 1.0 & 20.1 & 0.0 & 0.0 & 20.1 & 0.0 \\
\hline Mineral and energy resources & NA & 163.6 & 0.0 & 0.0 & 163.6 & 0.0 \\
\hline Other nonfinancial assets & 1.4 & 2.8 & 0.2 & 0.0 & 3.0 & 0.0 \\
\hline Financial assets & 22.2 & 49.5 & 2.0 & 33.6 & 44.7 & -40.5 \\
\hline \multicolumn{7}{|l|}{ by instrument } \\
\hline Monetary gold and SDRs & 0.0 & 0.0 & 0.0 & 0.6 & 0.6 & 0.0 \\
\hline Currency and deposits & 0.5 & 2.0 & 0.6 & 0.6 & 2.7 & -0.5 \\
\hline Debt securities & 9.4 & 13.4 & 0.1 & 12.0 & 13.4 & -12.1 \\
\hline Loans & 3.1 & 4.6 & 0.4 & 19.2 & 18.8 & -5.4 \\
\hline Equity and investment fund shares & 5.2 & 23.9 & 0.1 & 0.9 & 3.4 & -21.5 \\
\hline Otherfinancial assets & 4.0 & 5.7 & 0.7 & 0.3 & 5.8 & -0.9 \\
\hline Liabilities & 53.4 & 76.6 & 30.2 & 33.7 & 100.0 & -40.5 \\
\hline \multicolumn{7}{|l|}{ by instrument } \\
\hline SDRs & 0.4 & 0.4 & 0.0 & 0.0 & 0.4 & 0.0 \\
\hline Currency and deposits & 0.2 & 0.5 & 0.0 & 8.8 & 8.8 & -0.5 \\
\hline Debt securities & 28.5 & 28.6 & 0.0 & 0.0 & 16.5 & -12.1 \\
\hline Loans & 0.9 & 9.1 & 7.5 & 20.5 & 31.7 & -5.4 \\
\hline Equity and investment fund shares & 0.0 & 0.0 & 20.1 & 1.4 & 0.0 & -21.5 \\
\hline Insurance, pension, and standardized guarantee schemes & 19.0 & 29.0 & 0.6 & 0.3 & 29.9 & 0.0 \\
\hline Financial derivatives and employee stock options & 0.0 & 0.0 & 0.3 & 2.2 & 2.5 & 0.0 \\
\hline Other accounts payable & 4.4 & 8.9 & 1.7 & 0.6 & 10.4 & -0.9 \\
\hline NET FINANCIAL WORTH & -31.2 & -27.0 & -28.2 & -0.1 & -55.4 & 0.0 \\
\hline NET WORTH & NA & 209.2 & 0.0 & 0.0 & 209.2 & 0.0 \\
\hline \multicolumn{7}{|l|}{ STATEMENT OF OPERATIONS } \\
\hline Revenue & 24.3 & 34.0 & 4.8 & 1.6 & 40.4 & 0.0 \\
\hline Expense & 26.3 & 35.3 & 5.1 & 1.8 & 42.2 & 0.0 \\
\hline Net operating balance & -2.0 & -1.4 & -0.3 & -0.2 & -1.9 & 0.0 \\
\hline Net investment in nonfinancial assets & 0.3 & 1.3 & 0.6 & 0.0 & 1.9 & 0.0 \\
\hline Net lending/borrowing & -2.3 & -2.6 & -0.9 & -0.2 & -3.7 & 0.0 \\
\hline
\end{tabular}

Source: Australian Bureau of Statistics and IMF staff estimates.

In Australia, over the past ten years, cumulative deficits amounted to 25 percent of GDP while public investment created assets worth some 20 percent of GDP-a third of which was undertaken by public corporations that are not included in the general government sector. ${ }^{28}$ In addition, the net value of assets (excluding natural resources) and liabilities on the PSBS increased considerably due to price changes, despite some volatility over the time series. ${ }^{29}$

${ }^{28}$ Public investment refers to net acquisition of nonfinancial assets, which is part of the fiscal deficit (see Section II.B, Coverage of Flows). Traditional accounting of the deficit does not take account of the asset built up by such investment.

${ }^{29}$ The denominator effect reports 2007 nominal net worth as a share of 2017 GDP for ease of comparison. 
Overall, net worth deteriorated by 17 percent of GDP over the decade, significantly less than the increase in debt (Figure 9).

Figure 9. Australia: Public Sector Net Worth, 2007-2017

1. Drivers of Change in Net Worth (expressed as percent of 2017 GDP)

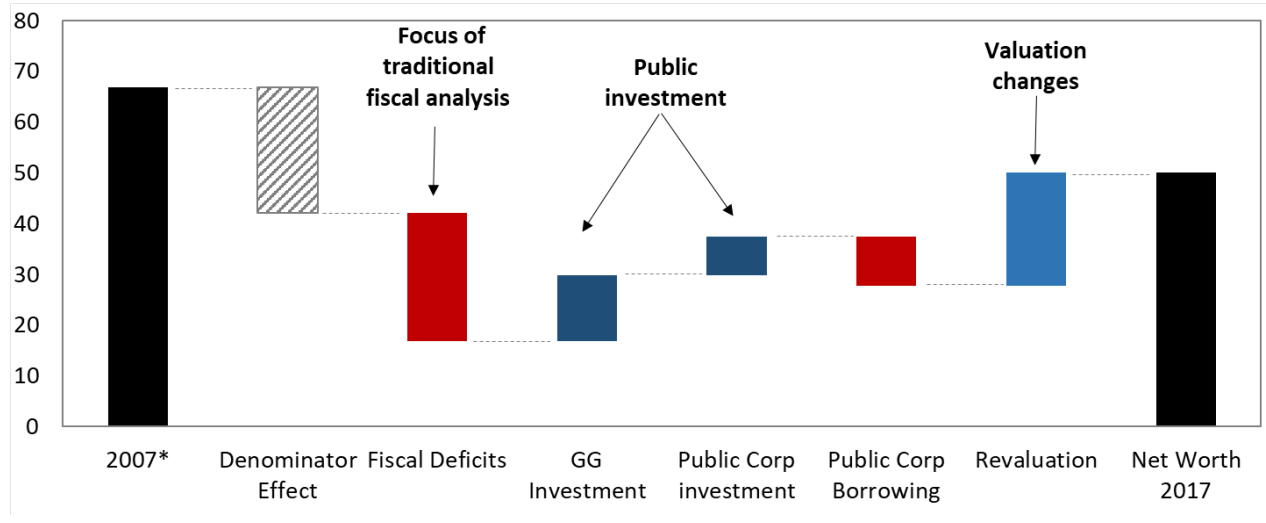

Note: * Expressed as percent of 2007 GDP

2. Annual Contribution of Drivers of Change in Net Worth (expressed as percent of GDP)

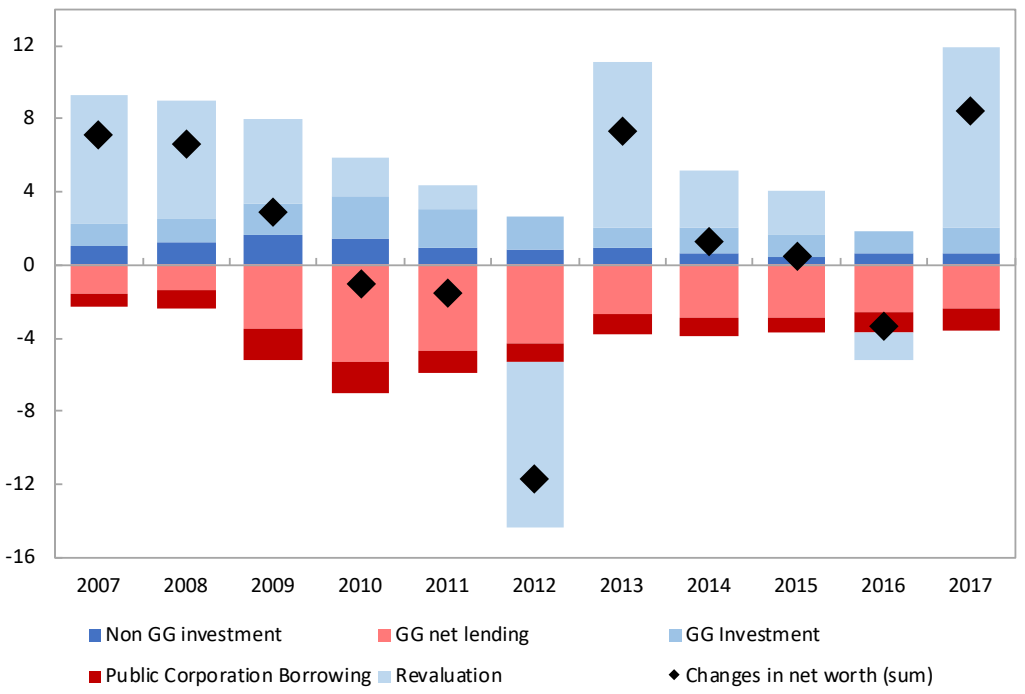

Source: Australian Bureau of Statistics and IMF staff estimates.

Decomposing changes in public wealth in this way allows the differentiation between types of economic events that reduce and add to public wealth. Those changes can be directly attributable to fiscal policy measures (transactions of public sector entities), or to events that are out of the direct control, such as changes in the value or volume of assets and liabilities. This adds transparency to the conduct of fiscal policy. A decomposition can be applied to both historical data and fiscal projections. ${ }^{30}$ This helps avoid the fiscal illusion that occurs when governments choose policies that on face value improve the fiscal position-lowering debt and

${ }^{30}$ Countries such as Australia and New Zealand, already project their balance sheets into the medium-term to demonstrate the impact of current policies on net worth. 
deficits-but don't change the net worth position, or in some cases reduce it. For instance, cutting back maintenance expenditure reduces the deficit and lowers debt, but, given the normal wear and tear (depreciation) of fixed capital, it also reduces the value of infrastructure assets, potentially by a greater amount than the saving. ${ }^{31}$ Alternatively, governments could execute quasi-fiscal policies through public corporations, for example, by obliging otherwise profitable public corporations to fund fuel subsidies, thereby pushing part of the deficit outside of the general government.

\section{The Relevance of Consolidation}

Including public corporations requires a consolidation of cross-holdings of assets and liabilities, to prevent its double-counting. Such cross-holdings can be a channel through which fiscal risks spread. ${ }^{32}$ For example, if the central government has invested in public corporations' bonds and the market value of these bonds deteriorate significantly due to poor performance of the public corporation, the eroding value of the public corporation's bond liabilities, will also erode the assets of the central government. The last column of Table 3 above shows an example of such consolidations. For example, debt securities issued by government held by public corporations and vice versa are subject to elimination. Similarly, the equity of the general government held in public corporations are eliminated and any currency and deposits or loan positions with public banks are eliminated in consolidation. These cross-holdings are country specific, with the largest typically between government and the central bank and other financial public corporations.

Consolidations can be large and have the potential to change the fiscal picture, as presented in traditional fiscal analysis. For example, in Japan, while gross outstanding public sector debt securities and loans were worth 288 percent of GDP in 2017, the majority were held by other public sector units, leaving 138 percent of GDP in the hands of private creditors (Figure 10, Panel 1). ${ }^{33}$ The same is true in the United States, albeit at a lower level, where the equivalent figures are 164 and 110 percent of GDP in 2016 (Figure 10, Panel 2). ${ }^{34}$ These differences are partly the result of quantitative easing $(\mathrm{QE})$, which has led to an unprecedented expansion of the asset holdings of many advanced economy central banks. From the perspective of the consolidated public sector, however, QE did not lead to a significant expansion of public sector asset holdings, since central banks implemented QE mainly by purchasing claims on other public sector units.

\footnotetext{
${ }^{31}$ Easterly (1999) and Irwin (2012) provide fuller account of these practices. Milesi-Ferretti and Mariyama (2006) distinguishes between structural reductions in debt that improve net worth, and non-structural reductions that reduce debt by decumulating assets.

32 This in in addition to the consolidations that are more routinely done at the general government level. See GFSM 2014, paragraphs 3.152-3.168.

${ }^{33}$ Koshima (2019) presents additional details on the evolution of Japan's PSBS.

${ }^{34}$ This includes Treasury holdings held by federal trust funds, including Old Age and Survivors and Disability trust funds (which are classified inside general government) as well as holdings of public corporations.
} 
Figure 10. Public Sector Debt by Holding Sector, 2001-17

(Percent of GDP)

1. Japan

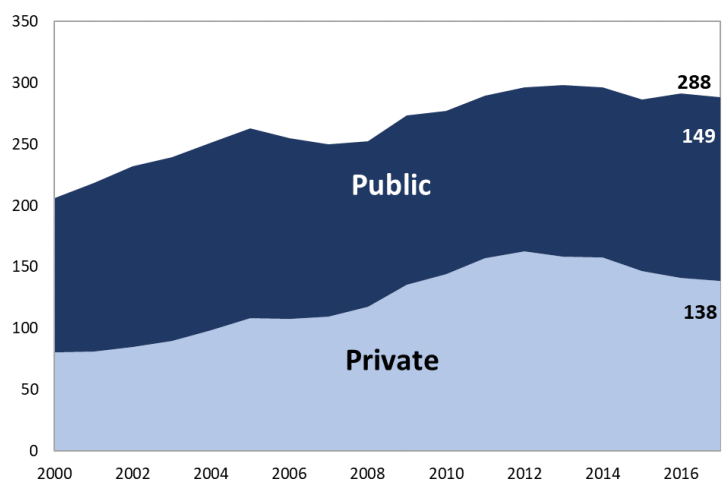

2. United States

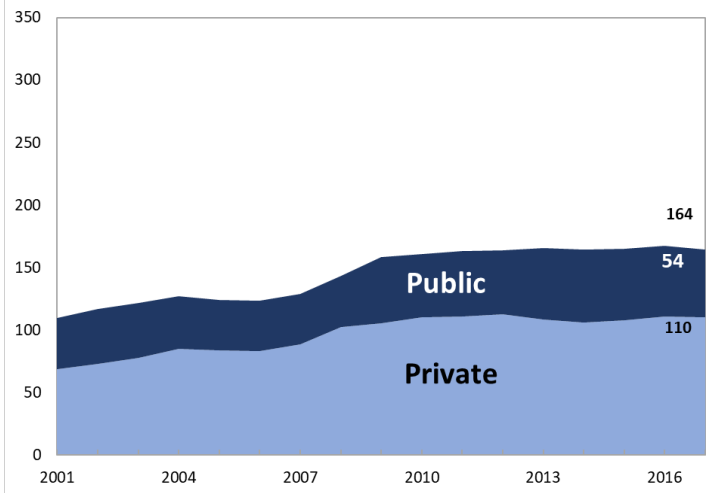

Source: IMF staff estimates.

\section{Cross-country Analysis}

Broadening the focus to public wealth sheds light on the assets that governments control, as well as on some types of liabilities that are normally not disclosed in traditional fiscal reports (Figure 11). For the sample of the 38 countries with data on public sector, assets average 218 percent of GDP, while liabilities around 196 percent of GDP. Net worth is positive on average but varies across countries. Most of the G7 countries have negative net worth, except for Canada. Countries with the highest value of natural resources have the largest assets and therefore have a positive net worth. Debt securities and loans are worth 93 percent of GDP at the general government level in the sample of 38 countries with full PSBSs. Existing pension obligations to public servants embody a stream of contractually required payments, amounting to 45 percent of GDP in these countries (Figure 12). These refer to pension obligations to public sector employees under social insurance schemes or employment-related pension schemes. ${ }^{35}$ Government assets comprise financial and nonfinancial assets, including natural resources. Financial assets (97 percent of GDP) are often marketable and relatively liquid, except for direct loans and unlisted equity holdings in public corporations, which may be less reliably valued. ${ }^{36}$

\footnotetext{
35 Following the Government Finance Statistics Manual (GFSM) 2014, pension obligations to private sector employees under pay-as-you-go social security schemes, such as the US Social Security or Japan's National Pension System and Employee Pension Insurance, are not included in the static balance sheet. They are instead disclosed as memorandum items and incorporated in future expenditure flows in the intertemporal balance sheet. See Box 1 for a discussion on the various types of pension arrangements

36 Some financial assets may be earmarked to specific uses or liabilities, such as deposits associated with grants for specific projects or assets tied to pension obligations. These encumbered assets are therefore unavailable for other financing needs under current institutional arrangements. However, examining these financial assets in a consolidated way may reveal potential benefits from improvements in asset management.
} 
Figure 11. Public Sector Balance Sheets

(Percent of GDP, 2016 or year of latest available data*)

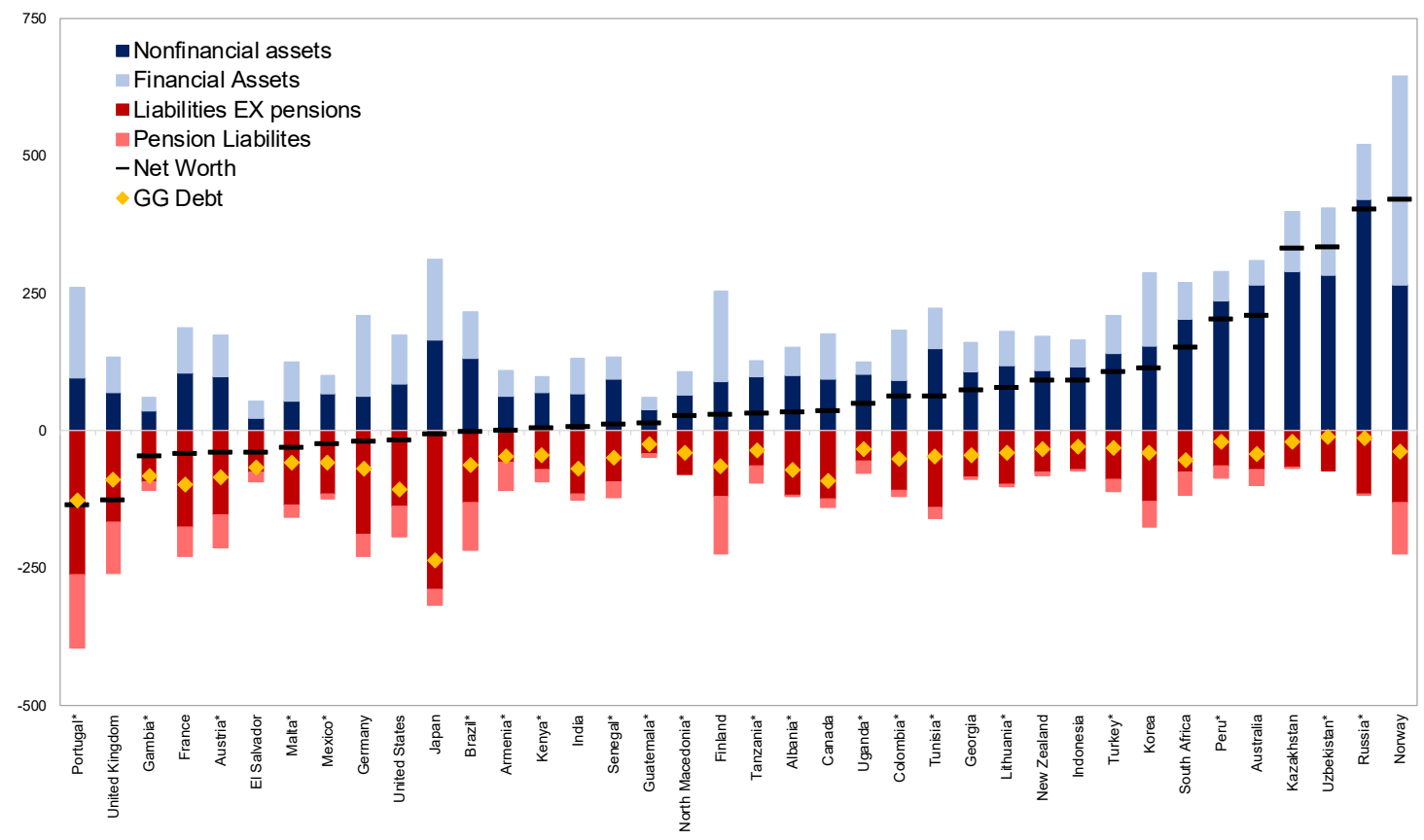

Source: IMF staff estimates

*Based on a single year of data, in most cases compiled as part of the Fiscal Transparency Evaluation: Albania, 2013; Austria, 2015; Brazil, 2014; Colombia, 2016; The Gambia, 2016; Guatemala, 2014; Kenya, 2013; Lithuania, 2017; Malta, 2016; Mexico, 2016; North Macedonia, 2016; Peru, 2013; Portugal, 2012; Russia, 2012; Senegal, 2016; Tanzania, 2014; Tunisia, 2013; Turkey, 2013; Uganda, 2015. Data are expressed in percent of GDP of the year to which the balance sheet data refer.

Nonfinancial assets include fixed assets (e.g. government buildings, infrastructure, machinery and equipment), land, natural resources, and some intangible assets (the most common of which is radio spectrum, an important source of cash for governments over time). Many of these assets comprise the public capital stock and play an integral role in delivering economic and social outcomes; they are typically illiquid and nonmarketable, or only marketable over the medium to long term (for example, through privatizations). In resource rich countries, natural resource reserves often represent the largest nonfinancial asset on the state's balance sheet.

Including the assets and liabilities of financial and nonfinancial public corporations in the PSBS shows the full scale of wealth under the government's control. ${ }^{37}$ It also allows for a stronger understanding of risk factors across the balance sheet, providing opportunities for better asset and liability management. The contribution of these corporations to public sector net worth in

\footnotetext{
${ }^{37}$ Due to data limitations, for many countries the analysis includes only central government public corporations.
} 
2016 is sizeable (19 percent of GDP, on average), across the sample of 17 countries, with some predominance of nonfinancial public corporations (Figure 13)..$^{38}$

In addition to net (financial) worth, a range of other indicators provide information on the state and resilience of the balance sheet. These include the standard measure of gross debt, as well as measures that explore risk mismatches and the degree of hedging present in the balance sheet. These measures provide a dashboard of indicators to consider when assessing fiscal health (IMF, 2018a and Yousefi, 2019).

Figure 12. Additional Elements of the Public Sector Balance Sheet (Percent of GDP)

1. Financial Assets

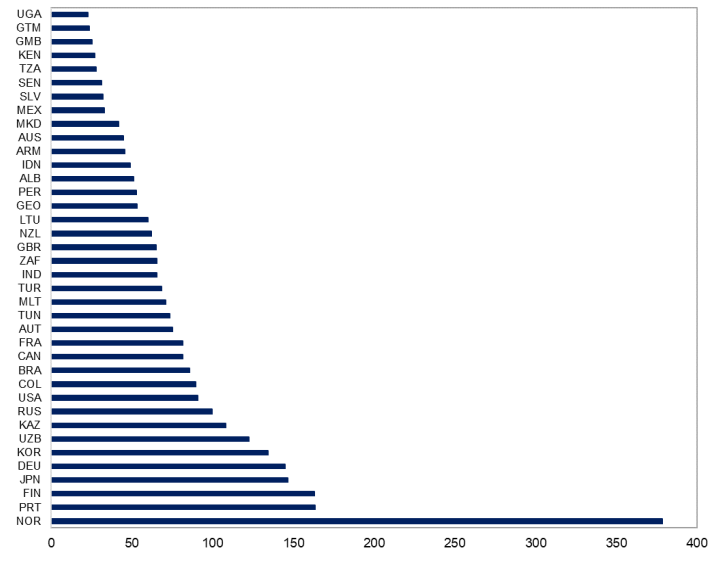

3. Public Corporation Assets

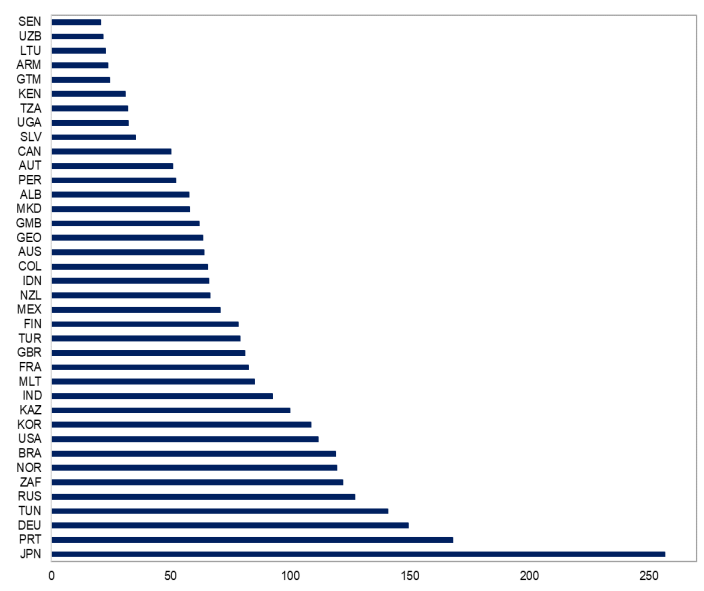

2. Nonfinancial Assets

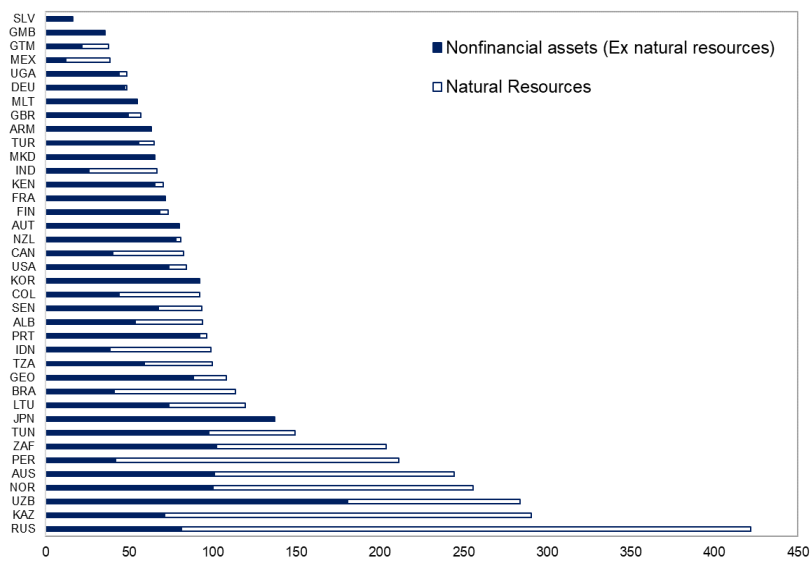

4. Pension Liabilities

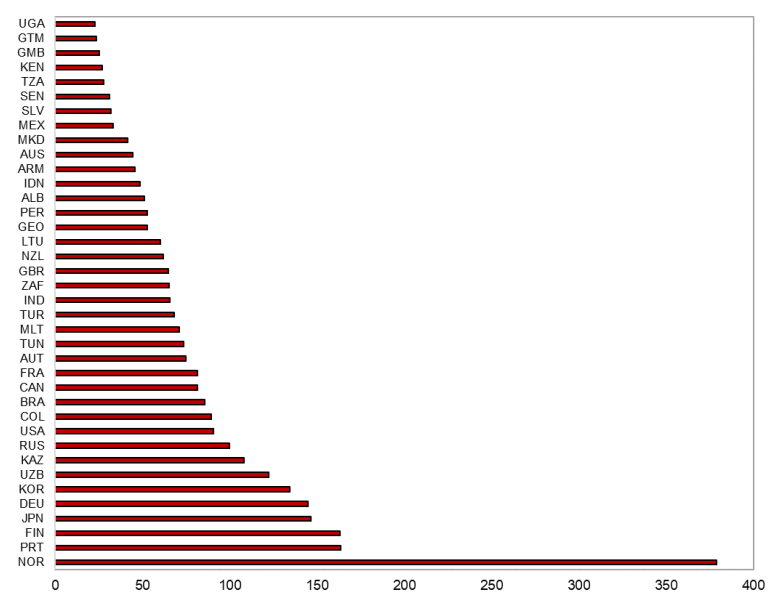

Source: IMF staff estimates.

Note: Data labels use International Organization for Standardization (ISO) country codes.

\footnotetext{
38 This contribution is measured by the difference between the corporations' assets and liabilities other than equity and investment fund shares. This is the equivalent in government finance statistics to the accounting standards concept of net worth (see further elaboration on "coverage of stocks" in Section II.B above).
} 
Figure 13. Equity Liabilities of Public Corporations, 2016

(Percent of GDP)

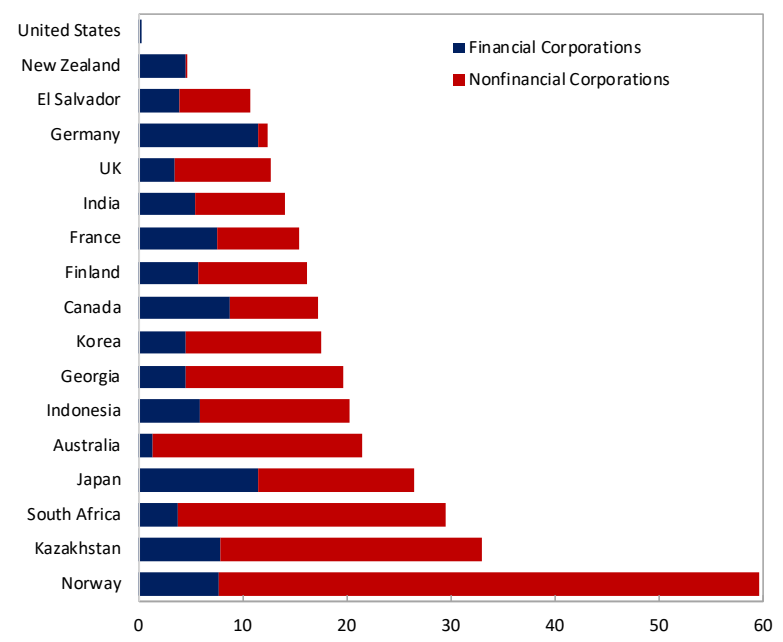

Source: IMF staff estimates.

Notes: United States' nonfinancial public corporations are accounted for in General Government, so they are excluded from this chart. Data sources permitting, equity liabilities of corporations with shares traded in the market are at market value; for other corporations or when market valuation are not available, they are at book value (see "coverage of stocks" subsection in Section II.B).

\section{Expanding Cross-country Analysis Through a Narrower Coverage}

Cross-country analysis can be expanded further by narrowing the coverage of institutions and stocks. For example, general government "basic" balance sheets, that exclude land, natural resources, and pension liabilities, are comparable across a significantly larger group of countries and territories. ${ }^{39}$ Furthermore, the modular structure of the database allows analysis to focus on narrower sets of data, for which additional details and breakdowns (e.g., by liquidity, currency, and volatility) can be compiled more easily than for the full public sector. ${ }^{40}$

"Basic" balance sheet size, composition and net worth vary considerably across the sample of 75 countries and territories (Figure 14). ${ }^{41}$ Assets average 100 percent of GDP, ranging from 398 percent of GDP in Norway to 15 percent of GDP in Tunisia, roughly evenly split between financial and nonfinancial assets. ${ }^{42}$ Against these assets stand average liabilities of 69 percent of GDP. As a result, static net worth in the sample varies from -111 percent of GDP in Greece to 348 percent

\footnotetext{
${ }^{39}$ General government balance sheets are necessarily smaller than those covering the public sector, as public corporations are only represented through the governments equity holdings.

${ }^{40}$ A more comprehensive analysis of liquidity, currency and volatility breakdowns can be found on Yousefi, 2019.

41 This section uses simple averages. For 7 countries the data are only available for central government.

42 Total assets excluding land and natural resources.
} 
of GDP in Norway, with an average positive net worth of 34 percent of GDP. Net financial worth averages -20 percent of GDP, with Greece and Norway again at the extremes.

Figure 14. General Government Balance Sheets, 2016 (Percent of GDP)

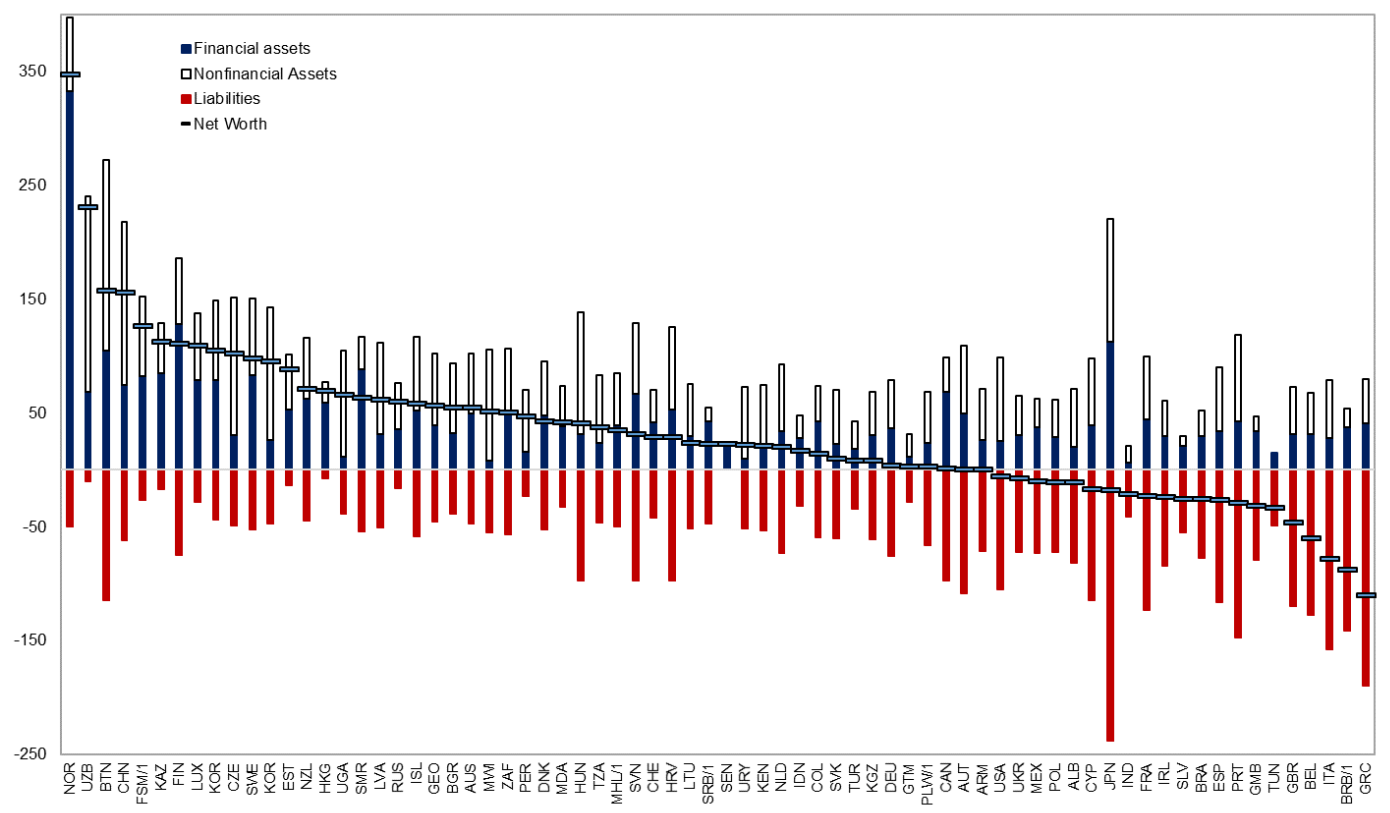

Source: IMF staff estimates.

Note: the data exclude land and natural resources assets and pension liabilities.

${ }^{1}$ Central government data.

\section{COMPILATION GUIDELINES}

The PSBS database illustrates that these datasets can be compiled even when traditional source data (financial statements or statistics) fail to cover all public sector units and respective assets and liabilities. The countries included in the PSBS database cover countries that already actively disclose PSBSs, in financial statements or statistics (e.g., Australia, New Zealand, or the United Kingdom), but also countries with limited available data on assets and liabilities (e.g., The Gambia or Senegal).

Balance sheets for these countries were compiled with varying degrees of difficulty, derived from the availability of source data. Some simplification was introduced in the compilation methods, to obtain a dataset that provides a fairly accurate order of magnitude. Simplifications were introduced both on the selection of the assets and liabilities to be included in the dataset (only the most material) or of units to cover (only the largest and macro-critical units in the sector).

This section provides guidance to potential compilers of these data-country officials, staff of international organizations, or financial sector analysts—on how to overcome the most common data source challenges. It also introduces tools and procedures that those users can avail 
themselves of to ensure the quality of the dataset and to proactively deal with the provisional nature of the dataset.

\section{A. Completing the Government Balance Sheet}

Establishing a complete government balance sheet, fully consistent with international accounting or statistical standards is challenging and takes time. It requires (i) the establishment of a full register of assets and liabilities of public sector units; (ii) the adoption of the accrual basis of recording, by which all subsequent transactions (additions, disposals, transfers, deterioration) are comprehensively recorded; and (iii) an accurate valuation of all those assets and liabilities. The considerable number and size of government units often result in accounting and reporting reforms taking more than a decade to implement. In developing countries, these issues are compounded with deficiencies in accounting systems and limited capacity of accounting officers. This should not prevent analysts from making estimates of the main categories of the balance sheet of the main central government unit (often referred to as the "State" or the budgetary central government). In the absence of a comprehensive accounting system that provides those elements, the following are the best alternative data sources for PSBS compilation (further elaboration on these sources is provided in the following sections):

- Central government debt statistics or reports from debt management units often provide fairly comprehensive data on the stock of debt securities issued or loans contracted by governments. ${ }^{43}$

- Data on domestic currency and deposits can often be sourced from banking surveys, while data on foreign currency and deposit holdings is available from international investment position data.

- Loans extended by governments are usually related to loans to employees, students, farmers, or housing. These type of loan schemes usually have their own set of records from which information can be drawn.

- Equity investments of government are usually related to investments in public corporations. Values of these investments can be derived from their balance sheets.

- Other receivables, such as tax receivables could be sourced from the tax administration system that usually carries records of taxes assessed but not yet received.

\footnotetext{
${ }^{43}$ A growing number of countries reports Public Sector Debt Statistics on a quarterly basis in a World Bank/IMF database available at http://datatopics.worldbank.org/debt/qpsd. Debt Management units' reports are also increasingly available, often supplemented by other administrative datasets such as registers of external loans or security-by-security data collection/reporting systems.
} 
- Other payables, such as amounts outstanding related to goods acquired but not yet paid, could be derived from the commitment register/control system of government, if such a system exists.

- Specialized social security or sovereign wealth fund reports often provide detailed information on the financial position of these entities.

The balance sheets of other government units (including those at the state and regional levels) could also be compiled, through surveys specifically designed for that purpose. ${ }^{44}$

\section{Data from Other Macroeconomic Statistics}

With the publication of the 1993 System of National Accounts, the national accounts became the overarching conceptual framework for all macroeconomic statistics, including the GFSM 2001. This integration was deepened with the latest versions of those manuals, the 2008 SNA, GFSM 2014, and the $6^{\text {th }}$ Balance of Payments Manual. The integration of macroeconomic statistics has the added benefit that all financial positions have a counterparty. So even if data for one sector of the economy are not available, this sector's exposure could be estimated from information disclosed by the other sectors of the economy. For every loan a government extends, there is someone who reports it as a liability. The government cash deposits are also a liability of banks, and government's equity assets show up in public corporations' financial statements as equity liabilities.

A good national accounts statistical system makes PSBS compilation easier, as these counterparty holdings are already tallied up and verified. PSBS compilers should use these data where they exist. For example, when statistical agencies compile comprehensive national balance sheets by institutional sector, these are the best data source for the PSBSs. They incorporate estimates for most categories of assets and liabilities, including those for which direct data are normally not available, such as fixed assets, land and natural resources, or pension liabilities.

Similarly, linkages exist between GFS and Monetary and Financial Statistics (MFS) that originate from governments having substantial transactions through and holdings in accounts held at financial corporations. Particularly central banks and other deposit-taking financial corporations often hold surplus cash for public sector entities. ${ }^{45}$ In addition, these financial corporations often invest their surplus resources in public sector debt instruments, such as debt securities, or governments borrow directly from the financial sectors in the form of loans to fund their net borrowing requirements. These relations will result in either a net claim of government on the financial corporations, or a net claim of these corporations on government. The net asset/liability

\footnotetext{
44 This section follows to some extent the guidance of the Quarterly Government Finance Statistics: Guide for Compilers and Users (IMF, 2013). It does not, however, include specific guidance on surveys, which can be consulted directly in that publication.

45 Depository corporations include deposit-takers and other financial institutions, such as money market funds, that issue liabilities included in broad money.
}

CInternational Monetary Fund. Not for Redistribution 
position between the general/central government sector and the financial corporations sector normally is consistent, or reconcilable.

In countries where governments fund their operations mainly through resident depository corporations, MFS data provide a good source for GFS data on some financial assets and liabilities. In such countries, governments' assets in the form of currency and deposits can be derived from the "Liabilities to central government" lines of the Central Bank Survey and the Other Depository Corporations Survey. When no data are available on the government's liabilities in debt securities and loans, the "Claims on central government" lines from the same surveys are usually a good proxy.

When the government finances itself substantially through nonresident units (foreign borrowing), or holds large foreign assets, the International Investment Position (IIP) statistics and External Debt Statistics (EDS) provide PSBS compilers with some relevant data. ${ }^{46}$ The relationships between nonresidents and general government units included in external sector statistics represent the impact of government operations on the external position of the economy. The structure of the external sector statistical framework is similar to the structure used in the GFS framework, and comprises (i) the IIP, which shows the stock value of the financial asset and liability stock positions between the residents of an economy and nonresidents at a reporting date; (ii) the balance of payments (BOP), which summarizes economic transactions (i.e., flows by mutual agreement) between residents and nonresidents during a specific time period; and (iii) the other changes in financial assets and liabilities, which shows flows due to economic events other than transactions between residents and nonresidents, and include valuation changes. The change in stock positions of the IIP is explained by the sum of transactions and other changes in financial assets and liabilities.

BOP/IIP statistics explicitly identify general government in "current transfers," "capital transfers," and flows and stocks in financial assets and liabilities. To the extent that BOP/IIP data are compiled using sources other than the government, this information can be used as an input to the PSBS compilation. Given the high degree of consistency between the financial instrument classification of the BOP/IIP/EDS and GFS classifications PSBS compilers can use this information almost directly. ${ }^{47}$

\footnotetext{
46 The World Bank/IMF Quarterly External Debt Statistics database http://datatopics.worldbank.org/debt/qeds provides detailed external debt data published by countries that subscribe to the IMF's Special Data Dissemination Standards (SDDS and SDDS Plus), and similar data for General Data Dissemination System (GDDS) countries that are in a position to produce the external debt data prescribed by the SDDS.

${ }^{47}$ However, it is important to be aware that the balance of payments clusters financial instruments into functional categories, including direct and portfolio investment.
} 


\section{Data from Other Administrative Datasets}

Tax and customs administrations and social security funds maintain registers of tax and social contribution claims, based on declarations and assessments, that are often the best available source data for government assets in the form of other accounts receivable. Care must be exercised, however, in order to avoid overstating the government assets as typically a significant share of revenue claims ends up not being collected by the collecting authorities. The difference between estimates based on declarations/assessments and expected collections represents a claim that has no real value and therefore should not be recorded as government revenue or other accounts receivable. In practical terms, the total claims from these registers should be corrected to account for the uncollectable element, calculated in reference to historical collection trends. When the uncollectable element is difficult to calculate, compilers often opt to record revenue on a time-adjusted cash basis. Under this basis, other accounts receivable arises only due to changes in collection patterns from one year to the other and are zero over time.

Ministries of Finance also typically establish commitment registers, to control expenditure of spending units. Where available, these registers are the best data source for the government's liabilities in the form of other accounts payable. When centralized registers are not available, the best alternative is analyzing the financial statements of the largest suppliers of goods and services to the government (normally construction or utilities companies), to identify any material claim they have on the government and imputing these data in the government balance sheet.

Often, governments have a public corporation's supervisory unit that regularly collects information on the net worth of the corporations and maintains records on the government's shareholding. ${ }^{48}$ Where available, this information can be used to calculate the value of government assets in the form of equity and investment fund shares.

\section{Other Data and Estimations}

The above data sources will often not include any information on the government's nonfinancial assets and pension liabilities. These items would only be available if comprehensive balance sheets of the general government would be compiled in the context of national accounts or government accounting. In the absence of such data, compilers could estimate these important categories of assets and liabilities, possibly using the methods described in more detail in Section II.C above:

- Fixed assets-perpetual inventory method estimates, or data from the IMF's capital stock and investment database (IMF 2017);

\footnotetext{
${ }^{48}$ Governments are increasingly disclosing to the public such information in public corporations annual monitoring reports. The structure of those reports and links to several examples can be found at the IMF's How to Note "How to Improve the Financial Oversight of Public Corporations" (IMF, 2016).
} 
- Natural resources (where deemed material - the net present value of the expected cash flows resulting from their commercial exploitation, based on projections of production and costs, or data from the World Bank's Changing Wealth of Nations report;

- Pension liabilities (where government employment-related pension schemes exist) actuarial/statistical estimates of accrued-to-date obligations, or estimates based on the current level of pension spending and active population projections.

- Land-estimates based on property registers combined with the respective average prices.

\section{B. Converting Financial Statements into Government Finance Statistics}

A close relationship exists between GFS datasets and financial statements compiled in line with accrual-based accounting standards, such as the International Public Sector Accounting Standards (IPSASs - used by government entities such as extrabudgetary funds or local governments) or the International Financial Reporting Standards (IFRSs_-often used by public corporations). Many of the accounting rules, concepts and procedures used in macroeconomic statistics are based on those used in public sector accounting. Therefore, these financial statements disclose broadly the same information, just in a different manner.

Preparation of reliable fiscal statistics is facilitated by application of high-quality accrual accounting standards, policies and procedures. Financial statements are usually subject to regular audit processes that provide some quality assurance. These audits and the subsequent corrective measures taken by the compilers of such statements ensure that the development of the quality of financial statements also translate into improvements in the quality of the GFS data.

As discussed above, when no public sector statistics are available, materiality considerations can be used to simplify the task of PSBS compilers. For public corporations, for example, compilers can use publicly available high-level balance sheet information - from statistical agencies' databases, government shareholding reports, or from financial databases, such as Orbis - to analyze the universe of corporations included in that information. This analysis should undertake: (i) the identification of units that are indeed public corporations, according to statistical standards; (ii) their ranking according to size, as measured by their total assets, for example; and (iii) the selection of the sample of units that would cover a significant share of the universe. ${ }^{49}$ Compilers can then focus on the conversion of the financial statements of that sample of units. The resulting data should be aggregated and extrapolated to the full universe, using the same indicator that was used to originally rank the units..$^{50}$

\footnotetext{
49 The experience of compilation for the PSBS database shows that the top 10 corporations normally account for around 90 percent of the assets of the total public corporations.

50 This process mimics the survey techniques described in more detail in the Quarterly Government Finance Statistics: Guide for Compilers and Users (IMF, 2013).
} 
GFS data and financial statements aim to record the finances of the same economic events. However, some differences become apparent when we investigate the details. The main purpose of GFS is to analyze and to evaluate the outcomes of fiscal policy decisions. GFS also shows the impact and linkages of government financial activities with those of the remainder of the economy and the rest of the world. GFS allows us to analyze the government's contribution to aggregate demand, investment and savings; it allows us to measure fiscal policy's impact on resource use, monetary conditions, fiscal burden, etc. The PSBS, in particular, allows us to also assess fiscal sustainability. Using the standardized template of the GFS also allows, national and international comparability of financial results.

On the other hand, general-purpose financial statements aim at evaluating the financial performance and position of an entity, and to provide transparency and hold management accountable for their actions, while at the same time inform decision-makers. These financial statements provide information to the public at large and resource providers on how the resources were utilized. The balance sheet (also called the statement of financial position) also facilitates the identification of resources and future claims on these resources. These financial statements are increasingly used as source data for GFS.

While there is overall considerable overlap between financial statements and GFS, some differences originate from the different objectives of the two sets of information. The balance sheet in both cases presents a comprehensive view of the stock of assets and liabilities at a specific point in time, making the financial statements' balance sheet a very good proxy to the GFS balance sheet. However, some conceptual, presentational and terminological differences exist and should be kept in mind when these financial statements are used as source for the compilation of the PSBS. ${ }^{51}$ The remainder of this section provides a brief overview of these differences, how to reconcile them and what adjustments need to be made to address them. ${ }^{52}$

\section{Classifications, Aggregation, and Terminology}

The PSBS compiler should be aware of potential classification differences when using financial statements as source data for GFS. Classification differences between GFS and financial statements are usually easy to correct by bridging financial statement items correctly to the GFS framework. While financial statements do not have a standardized format, there is some commonalities. Using these, an illustrative example of how these are converted to GFS are presented in Appendix II.

\footnotetext{
51 The GFSM 2014, Appendix 6 provides a detailed description of the similarities and differences. Readers can also refer to the latest edition of the Handbook of International Public Sector Accounting Pronouncements for more detailed explanations of the applicable reporting guidelines and standards.

52 Further elaboration on the conversion of financial statements to GFS, including with some practical examples, can be found in the GFS Compilation Guide for Developing Countries (IMF, 2011b).
} 
Accounting standards generally require that assets and liabilities be classified according to their liquidity as current (short-term, i.e. with a maturity equal to or less than one year) and noncurrent (long-term, i.e. with a maturity longer than one year). These standards are not very prescriptive about the detailed categories of assets and liabilities that should be presented on the face of the balance sheet. The implication of this is that the PSBS compiler that wishes to identify the various assets and liabilities by instrument/classification would need to investigate both current and non-current categories in the financial statements to calculate the value for the PSBS. For example, any nonfinancial asset that an entity plans to dispose of within the next financial year would likely be presented in the financial statements as current assets. The total of nonfinancial assets reported in the PSBS should therefore be the aggregation of nonfinancial assets reported under current and non-current. Similarly, financial instruments, such as deposits and debt securities, could be reported in two different places in the financial statement and would need aggregations for PSBS purposes.

Data in financial statements are often too aggregated to allow accurate bridging to the GFS framework. As a first resort, the compiler should investigate the notes to the financial statements. These often provide a more detailed breakdown of the items shown on the face of the financial statements. For example, the PSBS framework requires that financial assets and liabilities be classified according to whether the counterpart to the claim is a resident of nonresident. While this information is normally absent from the face of the financial statements, notes to the financial statements often present details on the nature of these claims, and often also list the counterpart to the claim that could be used to compile the cross-holdings of assets and liabilities for consolidation purposes. This information in the notes could often also be used to derive the breakdown into currency and maturity required in the PSBS.

The GFS also requires that the change in assets and liabilities are disaggregates into whether it resulted from a transaction, revaluation or change in volume of the asset. This information is often not available from the source document balances sheet. However, combining information obtained in the notes to the financial statement and information about the transactions in these assets captured in the cash-flow statement could help the compiler to derive the disaggregation.

Terminology used in financial statements may be different from that in GFS, and thus could give rise to some confusion. Because the types of financial instruments are not standardized in accounting standards, a term used-for example, "loans"-may very well include some debt securities, while a term such as "ABC Bond" may very well have the statistical characteristics of a loan. ${ }^{53}$ The details of the financial assets and liabilities should therefore be scrutinized before taking a final decision on bridging them with the standard definitions in GFS. In this respect, notes to the balance sheet are usually very helpful in describing in detail the nature and

\footnotetext{
${ }^{53}$ This problem is further compounded in cases where the compiler works with translated versions of financial statements. It has been found that quite often it is necessary to go back to the original language version of the financial statements to get clarity on the nature of the item.
}

CInternational Monetary Fund. Not for Redistribution 
characteristic of an item, which should determine the classification in GFS rather than the term used.

\section{Accounting standard and policies}

Financial statements always contain a note or statement of significant accounting policies. These notes should be reviewed to determine (i) the accounting standard or policy that was used;

(ii) any changes that may have occurred in these accounting policies since the previous publication of the financial statements; and (iii) the accounting principles used during compilation of the statements. The policy indicates whether the cash or accrual basis (or mix of it) was used in the compilation of the financial statements. It also discloses some details on specific compilation methods used. For example, an indication that fixed assets were valued at original historical costs signals the need to revalue these assets using market prices.

Such accounting policy notes to financial statements may also disclose information on the scope of assets and liabilities included in the statement. For example, it may disclose that significant subsoil assets exist, but that these were not included in the nonfinancial assets of the financial statements due to lack of information on the size or value of these assets. They may also indicate that taxes are recognized only on a cash basis and that financial assets related to these taxes are not known. In these cases, the compiler should employ some additional estimation techniques to recognize and value these assets more correctly on the PSBS. Should estimations not be possible, the compiler should take into consideration these deficiencies in the analysis of the data and disclose it appropriately in the metadata that accompany the PSBS.

\section{Recognition Criteria}

The key difference in recognition criteria relates to the scope of assets and labilities. On the accrual basis of reporting, the GFS recognize economic events when economic value is created, transformed, exchanged, transferred, or extinguished. To maintain symmetry in the macroeconomic accounts these events are recognized in the accounts of all parties involved at the time there is an irrevocable change of economic ownership. In contrast, financial statements recognize past events when the amount can reliably be estimated and when future outflows/inflows of resources are probable. This allows financial statements to recognize items that do not involve a counterparty entry, based on probability. The most significant probable assets and liabilities that are often recognized in financial statements and that should not be included in statistics are:

- Provisions for bad debts - when it is probable that some debts will not be collectable the financial statements recognize provisions for bad debts that will be offset in analysis against the asset; and

- Contingencies - contingent assets and liabilities are recognized in financial statements based on the probability that some future event may occur. For example, a contingent liability is recognized based on the probability that a guarantee may be called. Similarly, a contingent 
asset is recognized for deferred tax assets based on the probability that future profits will be subject to some tax allowances.

While GFS does not recognize such probabilities, some of it, such as the exposure to one-off guarantees and provisions for doubtful debts may be disclosed as memorandum items to the GFS balance sheet. This difference in recognition criteria will require that PSBS compilers adjust the value of assets and liabilities recorded in the financial statements; this being the case, compilers are encouraged to disclose a reconciliation between the two systems. It is important to note that excluding provisions when compiling GFS from financial statements would introduce discrepancies in the integrated framework. To overcome this, compilers may, from a practical standpoint, treat changes in provisions as a proxy for revaluations (i.e., as another economic flow).

\section{Valuation (Measurement) Methods}

GFS requires that current market prices be used for the valuation of all assets and liabilities. Allowance is made for the use of alternative valuation methods where an active market in which a price can be determined does not exist. For example, in the case of nonmarketable loans, the nominal value of the loan is presented on the GFS balance sheet. Accounting standards use fair value, historic cost, or other bases for the measurement of assets and liabilities. They require that similar assets and liabilities be valued consistently in the accounts and that the bases for valuation be disclosed.

Where an entity uses historical cost, for example to value nonfinancial assets, IPSASs often encourage disclosure of fair value if there is a material difference between the reported cost and the item's fair value. Should items be reported in the financial statements at fair value, these are usually a good proxy for market prices. However, if items are presented at historical cost or other bases of recording, the PSBS compiler needs to adjust the reported data to bring them close to the valuation principle used in GFS. This difference will result in a reconciliation item between the total assets/liabilities recognized in the two systems.

\section{Reporting Entities and Levels of Consolidation}

In macroeconomic statistics the basic reporting unit is an institutional unit, defined as an entity that is capable, in its own right, of owning assets, incurring liabilities, and engaging in economic activities in its own name. However, the main focus of the analysis is on groups of institutional units, that are consolidated into sectors or subsectors. These sectors and subsectors are determined by both the control of the entity and the economic nature of the entity. For this reason, all resident institutional units that are controlled, directly or indirectly by government units or resident public corporations are part of the public sector. As discussed above, the degree to which an entity is involved in market activities, will determine whether it is deemed a public corporation or a general government unit. Within the general government sector, subsectors are determined based on the level of government - central, state, or local - that the entity serves. These levels of government are consolidated to get an indication of economic activities at each 
level, regardless of control (e.g., all local governments are consolidated to get data for the local government subsector although none of these local governments are in control of each other).

In contrast, for financial statements the reporting unit is deemed to be an individual economic entity or group reporting entities. In the case of a group reporting entity, all entities under the control of one entity are consolidated. At the whole-of-government level, which is the highest level of consolidation of financial statements, the statements may include, in addition to government departments and subnational bodies, also government-owned businesses that primarily engage in market activities.

The implications of these differences for PSBS compilation are two-fold:

- Compilers need to determine whether these are individual financial statements, or whether they are the financial statements for a group entity. If the latter, the level at which such consolidation occurred should be determined, as well as whether these were consolidated using a line-by-line consolidation method or an equity consolidation method. ${ }^{54}$ If the financial statements include the consolidation result of public corporations under the control of the group reporting entity, the results of these public corporations should be eliminated from the data for the compilation of general government balance sheets. This can be a complex process, particularly in the case of line-by-line consolidation, and it may be worthwhile to rather use individual financial statement to compile data at the general government level.

- Compilers also need to determine counterparts to transactions that will allow the compiler to consolidate (i.e., eliminate transactions and stock positions between entities that are controlled and entities of the same nature). For example, in the compilation of PSBS, an analysis of the financial statements of one local government would need to identify the following counterpart stock positions separately: (i) the counterpart stock positions with all the entities that the local government control and that are part of the general government sector; ii) the counterpart stock position with all local government market enterprise that are under the control of the local government; (iii) the counterpart stock position with other local governments, which will allow consolidation of the subsector for local governments; and (iv) the counterpart stock position that it has with other units of the general government or public corporations subsectors, which will be used to conduct the ultimate consolidation of PSBS data.

\section{Data Validation and Quality Assurance}

The provisional nature of the PSBS dataset compilation methods described in the previous sections require that they be validated and subject to quality assurance. Quality assurance

\footnotetext{
54 Line-by-line consolidation requires that each item on the balance sheet of the parent unit is added to the corresponding item of the subsidiary unit before cross-holdings are eliminated. Equity consolidation entails the addition of the net asset value of the subsidiary as an equity asset to the balance sheet of the parent unit.
} 
procedures for PSBS are similar to those used for other GFS datasets: data should be internally consistent; all material units and categories of assets/liabilities should be reflected in the dataset; there should be no unexplainable breaks in the series; and the scale of main ratios should make analytical sense. While automation of these procedures is possible to some extent, they primarily require analysis and judgement by the compiler.

\section{Internal Consistency Checks}

Stock-flow consistency checks rely on GFS's integrated framework, by which there is a clear relationship between the stock and flow data (i.e., opening balance + transactions + other economic flows = closing balance). This type of consistency check assesses the degree to which changes between two consecutive balance sheets are explained by identified transactions and known other economic flows. The latter may not be actively compiled in the PSBS exercise, but if calculated as a residual difference between the sum of opening balance and transactions and the closing balance, it should be explainable, e.g., deriving from a depreciation of the currency, a change in prices of assets, the discovery of natural resources, a change in the discount rate, etc.

Consolidation is another aspect of internal consistency. As discussed above, the PSBS dataset includes not only the public sector aggregates, but also those of individual subsectors. The latter reflect stock positions vis-à-vis other subsectors, which must be eliminated from both parties' data in the consolidation process. The amounts subtracted to the assets of one subsector need to be equal to those subtracted from the liabilities of the counterpart subsector (this rationale applies at the level of specific financial instruments). As a result, the net aggregates (net worth or net financial worth) of the public sector need to be equal to sum of the subsectors' net aggregates.

\section{Consistency with External Sources}

External data sources often include references to PSBS data. For example, to the extent that PSBS were compiled using aggregate reports or publications, the PSBS aggregates can be checked and reconciled against the financial statements of major public sector units, media articles, estimates of third parties, or trends in government operations, financial market data, etc. This type of consistency checking should also cover the correspondence between variables of different macroeconomic datasets (as discussed above).

\section{Time Series Consistency Check}

Time series consistency checks analyze the reasons for significant changes in the main PSBS aggregates from one period to the other, and identifies the public sector units that contribute the most to those changes in the aggregates. Generally, a threshold for significance changes can be set, both in terms of percentage change and absolute changes (e.g., +/- 5 percent and +/$\$ 500 \mathrm{~m})$, with compilers required to check data changes that fall outside these thresholds. 


\section{Ratio Checks}

The characteristics of specific sections of the PSBS, allow for a verification of a set of ratios. For example, the value of assets/liabilities to GDP or of transactions to the stock of the relative assets (interest revenue/expense relative to stock of debt securities and loans, dividends relative to stock of equity assets, and rents to the stock of land) can be checked against other countries' ratios. Similarly, nonfinancial/financial assets to total assets can also be checked to identify anomalies in the dataset, e.g., nonfinancial public corporations with a predominance of financial assets or financial public corporations with a predominance of nonfinancial assets.

\section{Dissemination and Revisions Policy}

PSBS data, like other macroeconomic statistics, are subject to revisions. The main reason for revisions is the incorporation of improved and/or more comprehensive source data, which reflects the known trade-off between accuracy and timeliness. Because of this reason, revisions are more common for infra-annual data or preliminary annual data, that are sourced from unaudited data sources. Although less frequently, revisions can also derive from two other reasons: the correction of errors and omissions in initially reported data, and the adoption of new or revised statistical/accounting methodologies. ${ }^{55}$

Users often assess data accuracy and reliability by analyzing revisions, and therefore these need to be properly disseminated. Revisions are unavoidable and not a problem in and of itself, unless they remain unreported, are large, or perceived as biased. The IMF's Fiscal Transparency Code has a principle on historical major revisions, requiring that they be disclosed and explained. ${ }^{56}$ The analysis of differences between successive data releases should be disseminated for all major aggregates, and these should be accompanied by a study on historical trends on the size and direction of revisions. ${ }^{57}$ If large revisions are found to be consistent in one direction, changes should be made on either the data sources or the compilation methods to eliminate the bias.

Dissemination of data and their revisions should follow a predetermined regular schedule, which can be incorporated in the advance release calendar disseminated by the compiling unit. This schedule should identify the expected data status (estimate, preliminary, final) of successive releases of data, as well as an explanation of the reasons underlying each revision. The reasons behind data revisions outside the predetermined schedule should be explained in detail.

\footnotetext{
55 Further elaboration on each of these reasons, may be found at the IMF's Fiscal Transparency Handbook.

56 The Code presents different levels of practice for this principle: a basic level of practice would be achieved by the reporting of major revisions; good practice would in addition required that explanations are provided along with the major revisions data; the advanced level would be achieved if the disclosure and explanations are accompanied by a bridging table between the old and new time series.

${ }^{57}$ A good example of revisions disclosure can be found at the UK's Office of National Statistics release of Public Sector Finances.
} 


\section{CONCLUSIONS AND WAY FORWARD}

This paper has described the main features of the PSBS database, which includes comprehensive information on the assets and liabilities of the public sector and its subsectors for 38 countries covering 63 percent of global GDP. This database expands significantly, both in terms of institutional and stock coverage, the data available to fiscal policy decisionmakers. The database is the result of a multi-year compilation process by IMF staff, that culminated in the publication of the October 2018 Fiscal Monitor, devoted to Managing Public Wealth. The integrity of the datasets has benefitted from an extensive validation process, with respective country officials and IMF country desks.

Also included are basic balance sheets (excluding land, natural resources, and pension liabilities) covering the general government sector for another 30 countries, relying primarily on country data submissions for publication in the IMF's Annual Government Finance Statistics database.

This paper contributes to the description of sources and methods used in the compilation of the PSBS datasets, and guidelines for the compilation of comprehensive balance sheets, including for countries that are less advanced in the implementation of accounting/statistical reforms. The application of such guidance, will give analysts and policy makers access to the benefits of the balance sheet approach, described in detail in the Fiscal Monitor, while country reforms of their fiscal reporting are ongoing.

There is room for improvement in the PSBS database. Despite the efforts put into the compilation of the datasets, some gaps remain, particularly regarding (i) the number of countries and institutions for which data are available; (ii) the length of the time series, with a significant number of countries still having only one year of data available; (iii) the quality and cross country comparability of the estimates, particularly in the cases where the valuation or measurement of the assets and liabilities posed some difficulty; (iv) the availability of balance sheet strength and risk indicators; and ( $v$ ) the limited scope of intertemporal analysis. Looking ahead, as more data become available, from FTEs or from authorities' or IMF teams' compilations, attempts will be made to expand the database.

Finally, we rely on the feedback from users to address any problems they may encounter with the data. Notifications of any omissions or supplementary data sources is welcome and would be fully acknowledged..$^{58}$

\footnotetext{
${ }^{58}$ Suggestions can be sent to the authors (see the email addresses on the cover page of this paper).
} 
Appendix I. Time Series Availability in the PSBS Database

\begin{tabular}{|c|c|c|c|c|c|c|c|c|c|c|c|c|}
\hline \multirow{2}{*}{ Country/Territory } & \multicolumn{4}{|c|}{ Central Government } & \multicolumn{4}{|c|}{ General Government } & \multicolumn{4}{|c|}{ Public Sector } \\
\hline & NFAx & FA, $\mathbf{L x}$ & LNR & PENS & NFAx & FA, $\mathbf{L x}$ & LNR & PENS & NFAx & FA, $\mathbf{L x}$ & LNR & PENS \\
\hline Albania & & $2011-16$ & $2011-16$ & & $2011-16$ & $2011-16$ & $2011-16$ & $2011-16$ & 2013 & 2013 & 2013 & 2013 \\
\hline Armenia & 2016 & 2009-12 & & 2009-12 & 2016 & 2016 & & & 2016 & 2016 & & \\
\hline Australia & & $2000-16$ & $2000-16$ & $2000-16$ & $2000-16$ & $2000-16$ & $2000-16$ & $2000-16$ & $2000-16$ & $2000-16$ & $2000-16$ & $2000-16$ \\
\hline Austria & & $2000-16$ & & & $2000-16$ & $2000-16$ & $2000-16$ & $2000-16$ & 2015 & 2015 & 2015 & 2015 \\
\hline Barbados & & $2000-16$ & 2006-16 & & & & & & & & & \\
\hline Belgium & & $2000-16$ & & & & $2000-16$ & & 2014-15 & & & & \\
\hline Bhutan & & $2010-14$ & & & & $2010-14$ & & & & & & \\
\hline Brazil & & 2006-16 & 2014-16 & $2010-14$ & $2014-16$ & 2006-16 & $2014-16$ & 2010-14 & 2014 & 2014 & 2014 & 2014 \\
\hline Bulgaria & & $2000-16$ & & $2000-16$ & & $2000-16$ & & $2000-16$ & & & & \\
\hline Canada & 2000-16 & $2000-16$ & $2000-16$ & $2000-16$ & $2000-16$ & $2000-16$ & $2000-16$ & $2000-16$ & $2000-16$ & $2000-16$ & $2000-16$ & $2000-16$ \\
\hline China & & 2010-16 & & & & $2010-16$ & & & & & & \\
\hline Colombia & & 2008-16 & 2008-16 & & 2008-16 & 2008-16 & 2008-16 & 2016 & 2016 & 2016 & 2016 & 2016 \\
\hline Croatia & & $2002-16$ & & & & $2002-16$ & & & & & & \\
\hline Cyprus & & $2000-16$ & & & & $2000-16$ & & & & & & \\
\hline Czech Republic & & $2000-16$ & & $2000-16$ & $2000-16$ & $2000-16$ & $2000-16$ & $2000-16$ & & & & \\
\hline Denmark & & $2000-16$ & & & & $2000-16$ & & $2014-16$ & & & & \\
\hline El Salvador & 2003-16 & 2006-16 & 2003-16 & 2006-16 & 2003-16 & 2006-16 & 2003-16 & 2006-16 & 2003-16 & 2006-16 & 2003-16 & 2006-16 \\
\hline Estonia & & $2000-16$ & & & & $2000-16$ & 2000-14 & 2014-15 & & & & \\
\hline Finland & 2000-16 & $2000-16$ & 2000-16 & $2000-16$ & $2000-16$ & $2000-16$ & 2000-16 & $2000-16$ & 2000-16 & $2000-16$ & 2000-16 & $2000-16$ \\
\hline France & & $2000-16$ & & & $2000-16$ & $2000-16$ & 2000-16 & $2000-16$ & 2008-16 & 2008-16 & 2008-16 & 2008-16 \\
\hline Gambia, The & 2016 & 2016 & 2016 & 2016 & & & & & 2016 & 2016 & 2016 & 2016 \\
\hline Georgia & & 2012-16 & & $2012-16$ & 2012-16 & & 2012-16 & 2012-16 & 2012-16 & 2012-16 & $2012-16$ & 2012-16 \\
\hline Germany & & 2000-16 & & & $2000-16$ & $2000-16$ & 2000-16 & 2000-16 & 2001-16 & 2001-16 & 2001-16 & 2001-16 \\
\hline Greece & & $2000-16$ & & & & $2000-16$ & & & & & & \\
\hline Guatemala & & 2014 & & 2014 & 2014 & 2014 & 2014 & 2014 & 2014 & 2014 & 2014 & 2014 \\
\hline Hungary & & $2000-16$ & & & & $2000-16$ & & & & & & \\
\hline Hong Kong SAR & & & & & $2002-16$ & $2002-16$ & $2002-16$ & 2006-16 & & & & \\
\hline Iceland & & 2000-16 & & 2016 & & $2000-16$ & & 2013-16 & & & & \\
\hline India & 2003-16 & 2003-16 & 2003-16 & 2003-16 & & & & & 2004-16 & 2004-16 & 2004-16 & 2004-16 \\
\hline Indonesia & & 2008-16 & 2008-16 & $2010-16$ & 2008-16 & 2008-16 & 2008-16 & 2010-16 & 2010-16 & $2010-16$ & $2010-16$ & 2010-16 \\
\hline Ireland & & 2000-16 & & & & $2000-16$ & & 2014-15 & & & & \\
\hline Italy & & 2000-16 & & $2000-16$ & & $2000-16$ & & 2000-16 & & & & \\
\hline Japan & & $2000-16$ & & $2000-16$ & $2000-16$ & $2000-16$ & $2000-16$ & $2000-16$ & 2000-16 & $2000-16$ & $2000-16$ & $2000-16$ \\
\hline Kazakhstan & & $2012-16$ & & $2010-16$ & $2012-16$ & $2012-16$ & 2012-16 & 2010-16 & 2012-16 & $2012-16$ & 2012-16 & 2012-16 \\
\hline Kenya & & 2013 & & 2013 & 2013 & 2013 & 2013 & 2013 & 2013 & 2013 & 2013 & 2013 \\
\hline Korea & 2012-16 & 2012-16 & & $2002-16$ & $2000-16$ & $2002-16$ & 2000-16 & 2002-16 & 2002-16 & 2002-16 & $2002-16$ & 2002-16 \\
\hline Kyrgyz Republic & & 2014-16 & & 2014-16 & 2014-16 & 2014-16 & 2014-16 & & & & & \\
\hline Latvia & & $2000-16$ & & & & $2000-16$ & & 2014-15 & & & & \\
\hline Lithuania & & $2000-16$ & & & & $2000-16$ & & 2012-15 & 2016 & 2016 & 2016 & 2016 \\
\hline Luxembourg & & 2000-16 & & & & $2000-16$ & & & & & & \\
\hline Macedonia & 2013-16 & 2015-16 & & 2015-16 & 2016 & 2016 & 2016 & 2016 & 2016 & 2016 & & 2016 \\
\hline Malawi & & 2009-16 & & & & & & & & & & \\
\hline Malta & 2000-16 & 2003-16 & & 2003-16 & $2000-16$ & 2003-16 & & 2016 & 2016 & 2016 & 2016 & 2016 \\
\hline Marshall Islands & & 2008-16 & & & & & & & & & & \\
\hline Micronesia & & 2008-16 & & & & & & & & & & \\
\hline Mexico & 2016 & 2016 & 2016 & 2016 & 2016 & 2016 & 2016 & 2016 & 2016 & 2016 & 2016 & 2016 \\
\hline Moldova & & 2005-16 & & & & 2005-16 & & & & & & \\
\hline Netherlands & & 2000-16 & & & 2001-15 & $2000-16$ & 2001-15 & 2011-12 & & & & \\
\hline New Zealand & & 2006-16 & 2006-16 & 2006-16 & 2006-16 & 2006-16 & 2006-16 & 2006-16 & 2006-16 & 2006-16 & 2006-16 & 2006-16 \\
\hline Norway & & 2000-16 & & $2000-16$ & $2000-16$ & $2000-16$ & 2000-16 & 2000-16 & 2000-16 & $2000-16$ & $2000-16$ & $2000-16$ \\
\hline Palau & & 2008-16 & & & & & & & & & & \\
\hline Peru & & 2006-16 & & & 2006-15 & 2006-16 & 2000-16 & 2013 & 2013 & 2013 & 2013 & 2013 \\
\hline Poland & & $2000-16$ & & & & $2000-16$ & & 2014-15 & & & & \\
\hline Portugal & & $2000-16$ & & & $2000-15$ & $2000-15$ & 2000-16 & & 2012 & 2012 & 2012 & 2012 \\
\hline Romania & & 2000-16 & & $2000-16$ & & $2000-16$ & & 2000-16 & & & & \\
\hline Russia & & $2001-16$ & 2014-16 & 2012 & $2014-16$ & $2001-16$ & 2014-16 & 2012 & 2012 & 2012 & 2012 & 2012 \\
\hline San Marino & & $2002-16$ & & & & $2002-16$ & & & & & & \\
\hline Senegal & 2016 & 2016 & 2016 & 2016 & 2016 & 2016 & 2016 & 2016 & 2016 & 2016 & 2016 & 2016 \\
\hline Serbia & & 2007-12 & & & & & & & & & & \\
\hline Slovak Republic & & 2000-16 & & $2000-16$ & & $2000-16$ & & 2000-16 & & & & \\
\hline Slovenia & & 2004-16 & & $2000-16$ & & 2004-16 & & $2000-16$ & & & & \\
\hline Solomon Islands & & $2012-16$ & & & & & & & & & & \\
\hline South Africa & & $2000-16$ & & $2000-16$ & $2000-16$ & 2000-16 & 2000-16 & 2000-16 & 2001-16 & $2001-16$ & $2000-16$ & 2001-16 \\
\hline Spain & & 2000-16 & & $2000-16$ & & $2000-16$ & & & & & & \\
\hline Sweden & & $2000-16$ & & $2000-16$ & & $2000-16$ & & $2000-16$ & & & & \\
\hline Switzerland & 2000-16 & 2000-16 & 2000-16 & $2000-16$ & $2000-16$ & $2000-16$ & 2000-16 & 2000-16 & & & & \\
\hline Tanzania & 2014 & 2014 & 2014 & 2014 & 2014 & 2014 & 2014 & 2014 & 2014 & 2014 & 2014 & 2014 \\
\hline Tunisia & & 2013 & & 2013 & & 2013 & & 2013 & 2013 & 2013 & 2013 & 2013 \\
\hline Turkey & 2014-16 & 2008-16 & 2014-16 & 2013 & 2014-16 & 2008-16 & 2014-16 & 2013 & 2013 & 2013 & 2013 & 2013 \\
\hline Uganda & 2015 & 2015 & 2015 & 2015 & 2015 & 2015 & 2015 & 2015 & 2015 & 2015 & 2015 & 2015 \\
\hline Ukraine & & 2008-16 & & & & 2008-16 & & & & & & \\
\hline United Kingdom & 2000-16 & $2000-16$ & 2000-16 & $2000-16$ & $2000-16$ & $2000-16$ & 2000-16 & 2000-16 & 2000-16 & 2000-16 & $2000-16$ & $2000-16$ \\
\hline United States & 2001-16 & 2001-16 & $2001-16$ & 2001-16 & 2001-16 & $2001-16$ & $2001-16$ & 2001-16 & 2001-16 & 2001-16 & 2001-16 & 2001-16 \\
\hline Uruguay & & 2001-16 & & 2001-16 & & 2001-16 & & $2001-16$ & & & & \\
\hline Uzbekistan & 2016 & 2016 & 2016 & 2016 & 2016 & 2016 & 2016 & 2016 & 2016 & 2016 & 2016 & 2016 \\
\hline
\end{tabular}

Note: "Level" indicates the institutional coverage of central government data in the database, where CGin = central government, including social security funds; CGex = central government, excluding social security funds; and BCG = budgetary central government. NFAx = nonfinancial assets excluding land and natural resources; $F A=$ financial assets; $L x=$ liabilities, excluding pension-related liabilities; $L N R=$ land and natural resources; PENS = pension-related liabilities; and NA = not available. 


\section{Appendix II. Illustrative Conversion of Financial Statements to the PSBS Template}

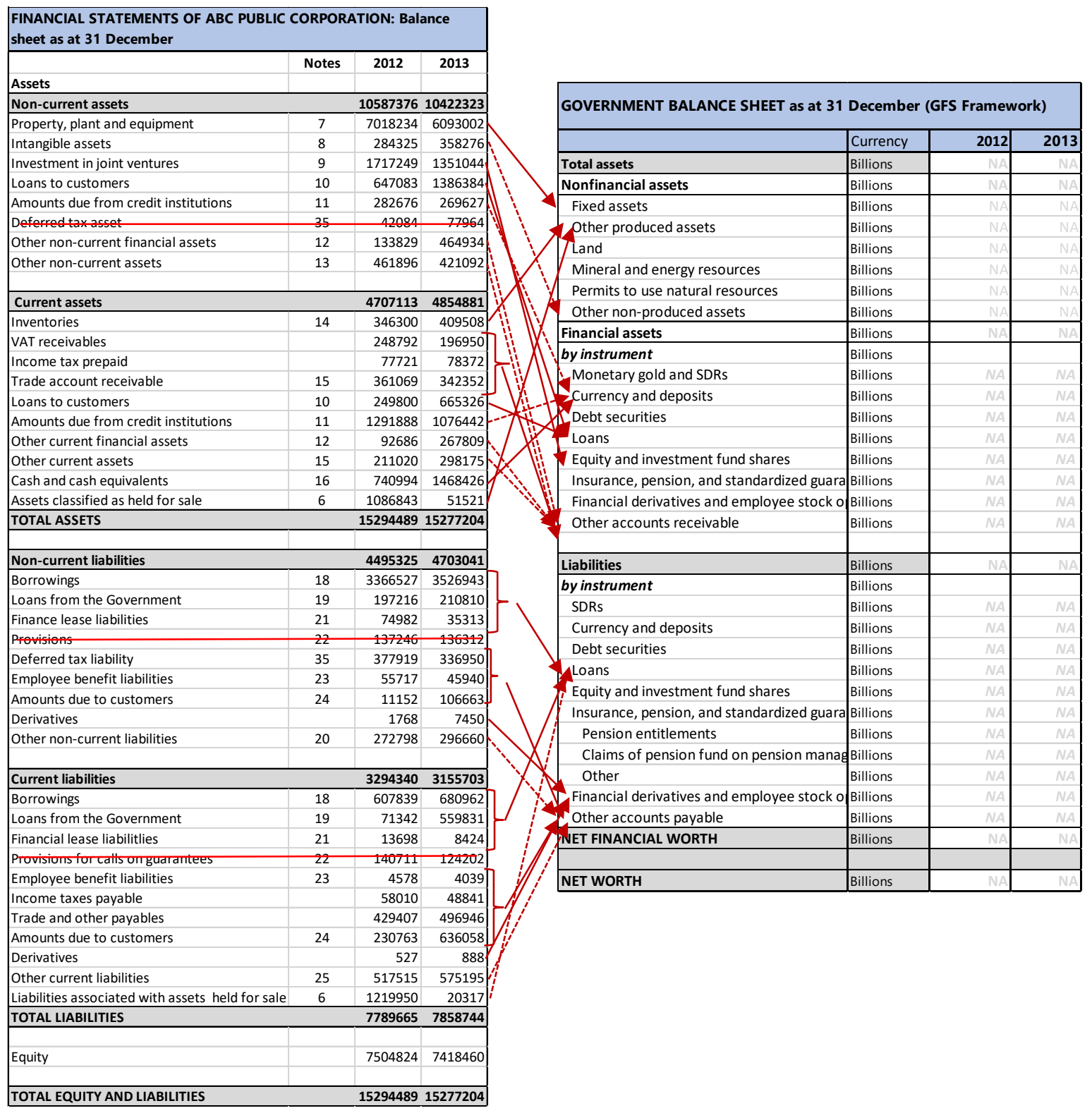

Notes: Dotted lines denote items for which additional information is required to make an accurate classification. For example, assets classified as held for sale will probably primarily comprise inventory in the case of a public corporations, and therefore an assumption was made to classify these as other produced assets. However, in the case of liabilities associated with assets held for sale, the category would need additional investigation to determine whether these liabilities represent only other account payable or whether some loans are included in the amount. Similarly, assumptions were made in classifying deferred tax assets and deferred tax liability. In the case of deferred tax assets, these are usually recognized based on the probability that some tax advantages will be enjoyed by the company pending certain conditions, therefore the GFS recognition criteria will not include this asset. However, in the case of deferred tax liabilities, the obligation to pay taxes in the future was established, but some arrangement allows these obligations to be settled in the future. 


\section{REFERENCES}

Abbas, S. M. A., N. Belhocine, A. El-Ganainy, and M. Horton 2011. "Historical Patterns and Dynamics of Public Debt-Evidence from a New Database," IMF Economic Review, Vol. 59, No. 4, pp. 717-742.

Abbas, S.M.A., N. Belhocine, A. El-Ganainy, and A. Weber 2014a. "Current Crisis in Historical Perspective," in C. Cottarelli, P. Gerson, and A. Senhadji, editors, Post-Crisis Fiscal Policy, pp. 161191 (Cambridge, MA: MIT Press).

Appleby, M., J. Harris, S. Hida, M. Norat, and A. Soler. 2018. "Fiscal Stress Test for The Gambia." IMF Country Report 18/100, International Monetary Fund, Washington, DC.

Bova, E., R. Dippelsman, K. Rideout, and A. Schaechter. 2013. "Another Look at Government's Balance Sheets: The Role of Nonfinancial Assets." IMF Working Paper 13/95, International Monetary Fund, Washington, DC.

Brede, M., and C. Henn. 2018. "Finland's Public Sector Balance Sheet: A Novel Approach to Analysis of Public Finance." IMF Working Paper 18/78, International Monetary Fund, Washington, DC.

Cabezon, E., and C. Henn. 2018. "Counting the Oil Money and the Elderly: Norway's Public Sector Balance Sheet." IMF Working Paper 18/190, International Monetary Fund, Washington, DC.

El Rayess, M., A. Halstead, J. Ralyea, J. Harris, and A. F. Tieman. 2019. "Indonesia's Public Wealth: A Balance Sheet Approach to Public Wealth." IMF Working Paper, International Monetary Fund, Washington, DC.

Easterly, W. 1999. "When Is Fiscal Adjustment and Illusion?" Economic Policy 14 (28): 56-86.

Escolano, J. 2010. "A Practical Guide to Public Debt Dynamics, Fiscal Sustainability, and Cyclical Adjustment of Budgetary Aggregates." IMF Technical Notes and Manuals, International Monetary Fund, Washington, DC.

Gaspar, V., F. Gonguet, and M. Stone. Forthcoming. "Perspectives on the Management of Public Wealth", Public Finance Act at 30 Conference proceedings, Victoria Business School. Wellington. New Zealand.

Gonguet, F., K. Hellwig, J. Harris, and A. F. Tieman. 2019. "Public Wealth in the United States." IMF Working Paper, International Monetary Fund, Washington, DC.

Irwin, T. 2012. "Accounting Devices and Fiscal Illusions." IMF Staff Discussion Note 12/02, International Monetary Fund, Washington, D.C. 
International Monetary Fund (IMF) 2011a3. "Public Sector Debt Statistics: Guide for Compilers and Users". Washington, DC. "Reassessing the Role and Modalities of Fiscal Policy in Advanced Economies," IMF Policy Paper, September 2013.

----- 2011b. "Government Finance Statistics: Compilation Guide for Developing Countries." Washington, DC.

----- 2012. "Fiscal Transparency, Accountability, and Risk". IMF Policy Paper, Washington, DC.

----- 2013a. "Public Sector Debt Statistics: Guide for Compilers and Users". Washington, DC.

----- 2013b. "Quarterly Government Finance Statistics: Guide for Compilers and Users".

Washington, DC.

----- 2014a. "Government Finance Statistics Manual". Washington, DC.

----- 2014b. "Update on the Fiscal Transparency Initiative". IMF Policy Paper, Washington, DC.

---- 2016. "How to Improve the Financial Oversight of Public Corporations." IMF How to Note, Washington, DC.

----- 2017. "Estimating the Stock of Capital in 170 Countries (Jan 2017 Update)." Washington, DC.

----- 2018a. "Managing Public Wealth." IMF Fiscal Monitor. Washington, DC.

----- 2018b. "Fiscal Transparency Handbook." . Washington, DC.

----- 2018c. "Capitalizing on Good Times." IMF Fiscal Monitor. Washington, DC.

----- 2019. "Fiscal Transparency Code." IMF. Washington, DC.

Koshima, Y. 2019. "Japan's Public Sector Balance Sheet". IMF Working Paper, International Monetary Fund, Washington, DC.

Lange, G. M., Q. Wodon, and K. Carey (eds.). 2018. "The Changing Wealth of Nations 2018". Washington, DC: World Bank.

Mbaye, S., M. Moreno Badia, and K. Chae. 2018. "Global Debt Database: Methodology and Sources" IMF Working Paper 18/111, International Monetary Fund, Washington, DC.

Milesi-Ferretti, G., and K. Moriyama. 2006. "Fiscal Adjustments in EU Countries: A Balance Sheet Approach." Journal of Banking and Finance 30(12): 3281-3298.

Rystad Energy. 2018. Upstream Database. 
Seiferling, M., and S. Tareq. 2015. "Fiscal Transparency and the Performance of Government Financial Assets." IMF Working Paper 15/9, International Monetary Fund, Washington, DC.

Traa, B., and A. Carare. 2007. "A Government's Net Worth." Finance and Development 44 (2): 46-49.

United Nations 1946. Public Debt 1914-1946, New York: United Nations.

Wilburn, D. R., D. I. Bleiwas, and N. A. Karl. 2016. "Global Stocks of Selected Mineral-based Commodities." In Scientific Investigation Report 2016-5152, US Geological Survey, Reston, VA.

United Nations. 2017. "World Populations Prospects: The 2017 Revision." New York.

Yousefi, S.R. 2019. "Public Sector Balance Sheet Strenght and the Macro Economy," IMF Working Paper, International Monetary Fund, Washington, DC. 